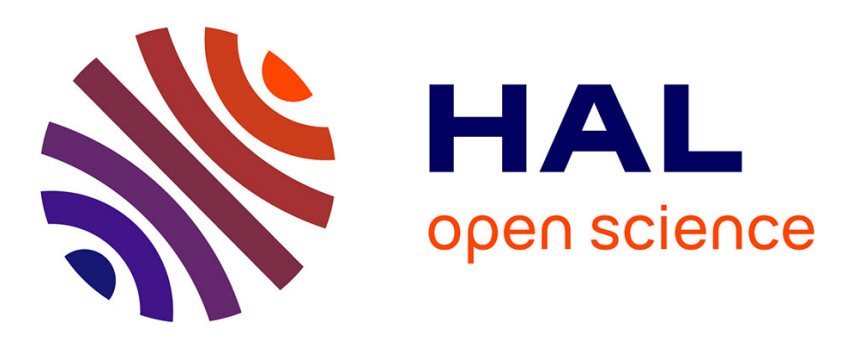

\title{
Evolution of the Ecuador offshore nonaccretionary forearc basin and margin segmentation
}

María José Hernández, François Michaud, Jean-Yves Collot, Jean-Noël Proust, Elia d'Acremont

\section{- To cite this version:}

María José Hernández, François Michaud, Jean-Yves Collot, Jean-Noël Proust, Elia d'Acremont. Evolution of the Ecuador offshore nonaccretionary forearc basin and margin segmentation. Tectonophysics, 2020, 781, pp.228374. 10.1016/j.tecto.2020.228374 . insu-02495764

\section{HAL Id: insu-02495764 \\ https://hal-insu.archives-ouvertes.fr/insu-02495764}

Submitted on 2 Mar 2020

HAL is a multi-disciplinary open access archive for the deposit and dissemination of scientific research documents, whether they are published or not. The documents may come from teaching and research institutions in France or abroad, or from public or private research centers.
L'archive ouverte pluridisciplinaire HAL, est destinée au dépôt et à la diffusion de documents scientifiques de niveau recherche, publiés ou non, émanant des établissements d'enseignement et de recherche français ou étrangers, des laboratoires publics ou privés. 


\section{Journal Pre-proof}

Evolution of the Ecuador offshore nonaccretionary forearc basin and margin segmentation

María José Hernández, François Michaud, Jean-Yves Collot, Jean-Noël Proust, Elia d'Acremont

PII: S0040-1951(20)30057-3

DOI: https://doi.org/10.1016/j.tecto.2020.228374

Reference:

TECTO 228374

To appear in:

Tectonophysics

Received date:

18 September 2019

Revised date:

10 February 2020

Accepted date:

15 February 2020

Please cite this article as: M.J. Hernández, F. Michaud, J.-Y. Collot, et al., Evolution of the Ecuador offshore nonaccretionary forearc basin and margin segmentation, Tectonophysics(2018), https://doi.org/10.1016/j.tecto.2020.228374

This is a PDF file of an article that has undergone enhancements after acceptance, such as the addition of a cover page and metadata, and formatting for readability, but it is not yet the definitive version of record. This version will undergo additional copyediting, typesetting and review before it is published in its final form, but we are providing this version to give early visibility of the article. Please note that, during the production process, errors may be discovered which could affect the content, and all legal disclaimers that apply to the journal pertain.

(C) 2018 Published by Elsevier. 


\title{
TECTONOPHYSICS R2
}

\section{Evolution of the Ecuador offshore nonaccretionary forearc basin and margin segmentation}

\author{
María José Hernández a,b,c , François Michaud b,d, Jean-Yves Collot ${ }^{\text {b }}$, Jean-Noël Proust e, Elia \\ d'Acremont ${ }^{\mathrm{c}}$ \\ a) Departamento de Geología, Escuela Politécnica Nacional, Ladrón de Guevara E11 - 253, Quito Ecuador \\ b) Université Côte d'Azur, IRD (Institut de Recherche pour le Développement), (CNRS) Centre National de la \\ Recherche Scientifique, Observatoire de la Côte d'Azur, GEOAZUR (laboratoire Géoazur), 06560 Valbonne, \\ France \\ c) Sorbonne Université, Institut des Sciences de la Terre de Paris (ISTeP), Campus Pierre et Marie Curie, 75252 \\ Paris, France \\ d) Sorbonne Université, Faculté des Sciences et Ingénierie, F-75252 Paris, France \\ e) Géosciences Rennes, CNRS, Université de Rennes 1, Campus de Beaulieu, 35042 Rennes cedex, France
}

Corresponding author: María José Hernández Salazar

Email address: maria-jose.hernandez@upmc.fr

Abstract

Forearc basins have developed along accretionary and nonaccretionary convergent margins. Here, we investigate the evolution of an offshore nonaccretionary-type forearc basin that has developed along the Ecuadorian convergent margin. We used 2D-Multichannel Seismic Reflection profiles to recognize five seismic units overlying the acoustic basement. The units were dated by correlation with wells and regional stratigraphy. They recorded the structural evolution of the margin into North, Central-North and Central-South margin segments identified from Gravity Free Air Anomalies. Intersegment transition zones accommodated deformation related to the margin segmentation, contributing to the development of shelf forearc depocenters. An offshore forearc basin (subunit L1a) developed on accreted oceanic terranes during the middle-to-late Eocene. The basin was affected by normal faulting during the Oligocene to early-middle Miocene (subunit L1b). This extension stage initiated during the rifting and oblique subduction of the Farallon plate beneath the Ecuador margin. The basin underwent an early-middle Miocene uplift outlined by unconformity U1 potentially associated with the subduction of the young Nazca plate, in a less oblique plate convergence environment. During the early-Pliocene, the Central-South margin segment individualized by uplift during the formation of unconformity U2. The Manta anticline, which developed in the intersegment transition zone, accommodated the segmentation. This event is associated with the arrival of the Carnegie ridge in the subduction. The North segment individualized by uplift during the Pliocene early-Pleistocene formation of the Pedernales structural high, which may coincide with a reactivation of the Canandé fault. Synchronously, unit L3 sediment recorded the subsidence of the Central-North segment, and strike-slip tectonics in the area of the Jama-Bahía depocenter. A mosaic of middle-to-late Pleistocene unit L5 depocenters that alternate with uplifted zones along the shelf likely recorded the subduction of the topographically irregular Carnegie ridge. The study provides a remarkable example of the evolution of a non-accretionary-type forearc basin.

Keyworks: convergent margin, nonaccretionary forearc basins, Ecuador, Neogene, Multichannel seismic reflection. 


\section{Introduction}

Forearc basins occur along all types of subduction margins (Dickinson and Seely, 1979; Dickinson, 1995) between the volcanic arc and the trench slope break (Karig and Sharman, 1975). They are a consequence of permanent deformation of the margin wedge in response to subduction processes, and as such their development reflects the interaction between the subducting and overriding plates (Hartley et al., 2000; Stern, 2002; Draut and Clift, 2013; Noda, 2016). Additionally, forearc basins are considered to be influenced by the thermal subsidence associated with the cooling of the adjacent arc massif or the cooling of an underlying accreted warm microplate (Xie and Heller, 2009). Forearc basins may trap sediment to thicknesses of several kilometers in a topographic depression that is bounded seaward by a structural ridge and landward by a more resistant backstop (Byrne et al., 1993). The ridge forms either from the uplift of an accretionary wedge or differential basal erosion, extensional tectonics and underplating at erosive margins (Draut and Clift, 2013). The volume of sediment accumulated in forearc basins likely differs at erosive and accreting margins (Noda, 2016), as the rate of sediment transport, the accommodation space available for sediment storage and the development of the outer forearc high contrast in both geodynamic settings.

The longitudinal continuity of forearc basins varies from hundreds of km-long, to an array of discrete and shorter sub-basins (Dickinson, 1995) that result from margin segmentation of various origins, including inherited basement structures (Mora et al., 2018), batholiths intrusions (Kimbrough et al., 2001), anomalous topography of the subducted plate (Gutscher et al., 1999) and strike-slip tectonics associated with oblique subduction (Karig et al., 1986; Ryan and Scholl, 1989). Double forearc basins, such as at the Cascadia convergent margin (McNeill et al., 2000) reveal a cross- margin segmentation characterized by inner (onshore) and outer (offshore) basins separated by a coastal range. Because the geodynamic regime of a convergent margin can fluctuate over time (ex: from accretion to erosion), and because forearc basins serve as a sedimentary archive of sea-level variations and subductionrelated tectonic, magmatic and erosion processes, exploring their tectonic and stratigraphic records is of paramount importance to decipher the geological history of forearc regions.

However, although the formation of accretionary-type forearc basins is relatively well understood (Von Huene and Scholl, 199, Dickinson, 1995; Stern, 2002, Noda, 2016 and 2018), the formation of nonaccretionary forearc basins remains poorly understood, apparently because they are less usual cases (Noda, 2016), but mainly because they form in an overall 
erosive environment that seems unfavorable to the development of a seaward bounding structural ridge allowing to trapping large quantities of sediment. So, an important question is how forearc basins develop on a tectonically erosive margin?

In South America, a nonaccretionary-type forearc basin has developed offshore Ecuador in relationship with the present day erosive convergent margin (Sage et al., 2006). This basin belongs to a double Cenozoic forearc basin (Lonsdale, 1978), which sediments derived from robust volcanism and intense erosion of the Northern Andes, was deposited over an oceanic basement made up of accreted Mesozoic terranes (Feininger and Bristow, 1980; Daly, 1989; Jaillard et al., 1997, 2000, 2009; Hughes and Pilatasig, 2002; Kerr et al., 2002; Vallejo et al., 2009). A Coastal Cordillera divides the onshore inner Manabí and Borbón basins (Jaillard et al., 1995; Deniaud, 2000; Reyes, 2013) from the offshore, yet poorly known outer basins, such as the Valdivia and Manta-Bahía basins (Deniaud, 2000) (Fig. 1). These offshore basins underlay the continental shelf and upper margin slope (Lonsdale, 1978 and 2005).

In this paper, we use Gravity Free Air Anomaly (FAA) and a dense grid of marine Multichannel seismic reflection (MCS) data to document the evolution of the Ecuadorian offshore sedimentary basin that extends from Santa Elena to Esmeraldas, and investigate the structural segmentation of the margin (Fig. 2). We specifically discuss the ages of the sedimentary sequences and regional unconformities, as well as the potential geodynamic causes of the structural evolution of the offshore forearc basin as a non-accretionary-type forearc basin.

\section{Geodynamic, geological and margin segmentation setting}

\subsection{Geodynamic}

The Ecuador convergent margin is characterized by the eastward subduction of the Nazca plate under the South American plate, at an average velocity of 5-7 cm / year (Trenkamp et al., 2002) (Fig. 1A). Geodynamic processes including the evolution and subduction of the Farallon-Nazca plates and Carnegie ridge, have influenced the tectonic development of the margin, where forearc basins have developed. The Nazca plate originated from the breakup of the Farallon plate during the early Miocene ( 23 Ma) (Lonsdale, 2005), an event that correlates with a decrease of the plate convergence obliquity and an increase of the convergence rate (Somoza and Guidella, 2012). The newly formed Nazca plate consists of the old-rifted Farallon lithosphere and the young Nazca lithosphere formed at Cocos-Nazca 
spreading center. According to Meschede and Barckhausen, (2001), the young Nazca lithosphere entered subduction beneath the Ecuador margin $14.7 \mathrm{Ma}$ ago. The combination of the subduction of the $400 \mathrm{~km}$-wide, 2-km-high and 14-19 km-thick Carnegie ridge (Lonsdale, 1978, Gustcher et al., 1999; Graindorge et al., 2004; Collot et al., 2009) and the partitioning of the oblique convergence induces the northward escape and the deformation of the North Andean Sliver (NAS, Fig. 1) (Pennington, 1981; Alvarado et al., 2016) (Fig. 1A). GPS work by Nocquet et al., (2014) indicates that the NAS migrates northeastward at 7.5$9.5 \mathrm{~mm} / \mathrm{yr}$, and that the convergence rate between the Nazca plate and the NAS is $4.7 \mathrm{~cm} / \mathrm{yr}$ in an $83^{\circ} \mathrm{E}$ direction (Fig.1B). Although the Ecuadorian geodynamic processes are believed to have been influenced by the Carnegie ridge subduction (Michaud et al., 2009), the age of the initiation of its subduction varies from $2 \mathrm{Ma}$ (Lonsdale, 1978), 5-6 Ma (Collot et al., 2009) 2-8 Ma (Gutscher et al., 1999), to 15 Ma (Spikings et al., 2010).

\subsection{Geology}

The modern Ecuadorian forearc formed after the accretion of oceanic terranes against the South American continental margin. The accretion occurred either in several episodes at $\sim 75$, $\sim 68$, and $\sim 58$ Ma (Feininger, 1987; Hughes and Pilatasig, 2002; Kerr et al., 2002; Jaillard et al., 2009), or during a single phase dated 75-65 Ma (Vallejo et al., 2009). Consequently, the forearc basement consists of oceanic blocks (Luzieux et al., 2006; Vallejo et al., 2009; Aizprua et al., 2019) (Fig. 1B) limited or deformed by crustal faults (Reyes and Michaud, 2012). The Canandé, Jama, Jipijapa, Colonche and La Cruz crustal faults bound the onshore sedimentary basins (Fig. 1B). Morphometric evidences suggest that the Canandé and Jama faults are active (Reyes, 2013; Reyes et al., 2018). The offshore prolongation of theses faults is unknown, with the possible exception of the Jama fault (Collot et al., 2004).

The margin basement dated from the Cretaceous is called the Piñón Formation (Feininger and Bristow, 1980; Mamberti et al., 2003; Luzieux et al., 2006; Vallejo et al., 2009). It is overlain by volcanoclastic turbidites of the Cayo Formation of late Cretaceous age that passes laterally to volcanoclastic turbidites, basaltic flows, ash beds of the San Lorenzo Formation. This Formation extends up to the early Paleocene (Fig. 3), (Benítez, 1995; Jaillard et al., 1995 and 1997). The Cayo and San Lorenzo Formations deposited before (Benítez, 1995; Jaillard et al., 1995 and 1997), or during (Vallejo et al., 2009) the accretion of the oceanic terranes. During the terranes accretion, the sedimentation of the southwestern part of Ecuador was marked by Paleocene conglomerates and coarse turbidites of the Azúcar Formation (Fig. 3) (Benítez, 1995; Jaillard et al., 1995; Witt et al., 2019).The post-accretionary period includes Early 
Eocene sediments represented by the calcareous sequences of the San Eduardo, Ostiones and Santiago Formations (Fig. 3), which overly unconformably the older Formations (Bristow and Hoffstteter, 1977; Evans and Whittaker, 1982; Ordóñez et al., 2006; Jaillard et al., 1995 and 1997). This sedimentation was followed by the regional clastic sequence deposited during the early and middle Eocene represented by the Ancon Group, the Zapallo and San Mateo Formations, which are lateral equivalents to each others (Benítez, 1995). The coastal area emerged during the Oligocene (Jaillard et al., 1995; Benítez, 1995), forming an outer forearc high identified along the Santa Elena peninsula (Witt et al., 2019) and the modern forearc basins began to develop along the margin (Jaillard et al., 1995; Benítez, 1995) (Fig. 1B). The sedimentation initiated by the deposition of the coarse grained Zapotal and pelitic Playa Rica and Pambil Formations (Benítez, 1995; Jaillard et al., 1995; Deniaud, 2000; Lopez Ramos, 2009; Witt et al., 2019). After a hiatus at the Oligocene-Miocene boundary (Benítez, 1995; Deniaud, 2000), the sedimentation continued during the early Miocene with the pelitic deposition of the Tosagua Group (Dos Bocas, Viche and Villingota Formations; Fig. 3) (Benítez, 1995; Deniaud, 2000). After a hiatus at the top of the Tosagua Group (Deniaud, 2000; Reyes, 2013), marine sandstones of the Angostura Formation (Fig. 3) deposited during the middle Miocene (Deniaud, 2000, Cantalamessa et al., 2007). During the late Miocene, the pelitic sequence of the lower Onzole Formation overlaid the Angostura Formation in transitional contact (Deniaud, 2000; Reyes, 2013). A regional discontinuity at the boundary between the Mio-Pliocene separates the Lower and Upper Onzole Formations (Deniaud, 2000; Di Celma et al., 2010). The Upper Onzole Formation called the Borbón Formation by Reyes (2013) consists of three members separated from each other by unconformities (Reyes, 2013) (Fig. 3). Offshore, in the Manglares basin (Fig. 1), based on seismic data analysis, five acoustic units of sedimentary nature (Units A-E) were identified separated by unconformities (U1-U5), resting over the interpreted oceanic basement (Unit F) (Fig. 3), (Marcaillou and Collot, 2008).

\subsection{Margin segmentation}

Several studies have shown that the Ecuador margin is segmented on a large scale. Gailler et al. (2007) based on wide angle seismic data, proposed three crustal segments in the subducting Nazca plate: the segment from latitude $3^{\circ} \mathrm{S}$ to $2^{\circ} \mathrm{S}$ is characterized by a $7-\mathrm{km}$ thick oceanic crust; the segment from latitude $2^{\circ} \mathrm{S}$ to $1^{\circ} \mathrm{N}$ reveals an over-thickened oceanic crust (15 to $19 \mathrm{~km}$ ) corresponding the Carnegie ridge; and the segment from Latitude $1^{\circ} \mathrm{N}$ to 
the North exhibits a $5 \mathrm{~km}$-thick oceanic crust. The crustal thickness variations of the downgoing plate appear to correlate with a segmentation of the upper plate, as suggested by Lonsdale (1978), Gutscher et al. (1999) and Collot et al. (2009). Collot et al. (2004) proposed a seismo-tectonic transverse segmentation of the Ecuador margin wedge based on MCS evidences for the offshore prolongation of upper plate crustal fault systems and their correlation with the boundaries of interplate rupture zones associated with great earthquakes.

\section{Data and methods}

A dense grid of 2D multi-channel seismic (MCS) data was acquired since the 1970 for the oil exploration in the Ecuadorian margin. SCAN MCS data were acquired in 2009 using a 4000-ci (65.5L), 20-80 Hz frequency air gun seismic source, and a 640-channel, 8-km-long streamer. Shots were fired every $25 \mathrm{~m}$, providing a 160-fold coverage. SCAN MCS data were fully processed by SINOPEC (China Petroleum and Chemical Corporation) for Petroecuador through classical steps including multiple elimination, spherical divergence compensation, predictive deconvolution in the Tau-P domain, pre-stack noise attenuation, stacking, and prestack time migration. Additionally, Western Geophysical Company MCS data (1975 and 1980), academic high-resolution ATACAMES MCS data (Michaud et al., 2016) and deep penetration SISTEUR data (Collot et al., 2004) were used (Fig. 2) to perform this work. The seismic interpretation respected the stratigraphy criteria defined by Mitchum et al. (1977) and Vail et al. (1977) and was done in PETREL software (Schlumberger) to generate sTWTT isodepth and isopach maps (Fig. 4 and 7).

Offshore borehole data (Fig. 2) from the Caráquez-1 well (Quintana Petroleum Corp., 1971 unpublished report; Hernández, 2012) and the Montañita-1 well (Belco Petroleum Ecuador Inc. 1988, unpublished report) were used to validate the seismic interpretation and the correlation with the onshore stratigraphy. The free air gravity anomaly grid used in this work (Fig. 2) was derived at sea from the CryoSat-2 and Jason-1 satellite altimetry and onshore from the global gravimetric model EGM2008 (Earth Gravitational Model 2008) (Sandwell, et al., 2014). This grid is locally complemented on the shelf and onshore by highresolution aero-gravimetric data (Sander Geophysics Limited, 2011, unpublished report).

\section{Results}

4.1 Shelf segmentation from satellite gravity

Gravity Free Air Anomaly (FAA) (Sandwell et al., 2014) along the Ecuadorian shelf 
shows values reaching -120 and 80 mGals (Fig. 2). Because of the relatively constant water depth of the shelf $(80-100 \mathrm{~m})$ (Fig. 1B) the FAA is considered as a proxy for depth-tobasement and believed to reflect the 1st order geological and structural margin segmentation. According to the mean gravity value for each shelf segment, we subsequently divided the shelf into North, Central-North, Central-South and South Segments (Fig. 2). The North segment located offshore Galera Peninsula is characterized by a positive roughly N-S trending gravity anomaly (+20 mGals, $\boldsymbol{a}$ anomaly in Figure 2). The Central-North Segment extends offshore from the Galera peninsula to Bahía de Caráquez. This segment is characterized by three roughly NE-SW trending negative gravity lows reaching -30 mGals (c, $\boldsymbol{e}$ and $\boldsymbol{f}$ anomalies in Fig. 2). The gravity lows are separated by a NW-SE trending anomaly $\boldsymbol{b}$ reaching $0 \mathrm{mGal}$, and NE-SW trending anomaly $\boldsymbol{d}$ reaching $+20 \mathrm{mGals}$ (Fig. 2). The CentralSouth segment extends from Bahía de Caráquez to the South of Santa Elena peninsula. This segment is characterized by a positive gravity anomaly reaching on average $+50 \mathrm{mGals}$ (Fig. 2). The regional anomaly shows peaks up to $+80 \mathrm{mGals}(\boldsymbol{g}, \boldsymbol{i}, \boldsymbol{j}$ and $\boldsymbol{l}$ anomalies in Fig. 2) separated by relative gravity lows of $+40 \mathrm{mGals}(\boldsymbol{h}, \boldsymbol{k}$ and $\boldsymbol{m}$ anomalies, Fig. 2). This alternation of relative negative and positive gravimetric anomalies seems to underline a NWSE structural trend. Finally, the South segment located in the Gulf of Guayaquil shows a regional ENE - WSW negative anomaly lower than -100 mGals ( $\boldsymbol{n}$ in Fig. 2). In the next sections, we interpret the MCS reflection profiles to determine the geological structures that are potentially associated with the segmentation derived from the FAA.

\subsection{Seismic Units}

We identified five seismic units L1 to L5 from the oldest to the youngest above the acoustic basement (Fig. 3 and 5). These units are separated by regional unconformities U1, $\mathrm{U} 2, \mathrm{U} 3, \mathrm{U} 5$ and one local unconformity U4. The cumulated sedimentary thickness above the acoustic basement shows large variations that are used to define the spatial arrangement of the Pedernales, Bahía-Jama, Caráquez, La Plata, Monteverde and Valdivia off-shore sedimentary depocenters within the outer forearc basin (Fig. 4).

\subsubsection{Acoustic Basement}

The deepest band of reflectors recognized in the margin is high-amplitude but irregular-peaky and discontinuous. This band of reflectors tops chaotic reflections returned from within the acoustic basement and is overlain locally by down lapping reflectors of 
seismic unit L1 (Fig. 6) so that the band of reflectors is interpreted as major nonconformity Ub. The TWTT isodepth map of Ub (Fig. 7) shows an elevated acoustic basement in the North and Central-South segments, whereas it is depressed in the Central-North segment. The depth distribution of Ub closely reflects the spatial variations of FAAs (Fig. 2) supporting that the proposed FAA-based segmentation of the shelf is dominantly structural.

\subsubsection{Seismic Unit L1}

Seismic unit L1 deposited over nonconformity Ub and reaches up to $2.5 \mathrm{~s}$ TWTT in thickness (Profile 433: CDP 5500 in Fig. 6 and Fig. 10A). The seismic facies of the unit varies from low (Profile 868 in Fig. 8) to high (Profile n-32 in Fig. 9) amplitudes and the seismic configuration changes from chaotic (Profile 425 in Fig. 5) to sub-parallel (Profile 868 in Fig. 8). These vertical variations allow interpreting a lower (L1a), and an upper subunit (L1b) separated by unconformity U0. Unconformity U0 is defined by truncations of L1a reflectors and by onlaps of L1b reflectors (Profile n-32: CDP 1200-1700 in Fig. 9). Subunit L1a shows a thickness of 0.4 to $0.8 \mathrm{~s}$ TWTT. Its seismic facies is highly variable from transparent to chaotic and well bedded (Profiles 425, 433, and n-32 in Fig. 5A, 6 and 9). Subunit L1b is thicker than L1a and can reach 1.5 s TWTT (Profiles 433 and n-32 in Fig. 6 and 9). Its seismic facies is well bedded with subparallel (Profile 868 in Fig. 8) to divergent (Profile n-32 in Fig. 9) configurations. The upper boundary of unit L1 is defined by the truncation of its reflectors (Profile 433 in Fig. 6), which forms angular unconformity U1. This surface is generally smooth (Profile 433 and Profile 441: CDP 4000-5300 in Fig. 6), although it can be undulated in some areas (Profile 441: CDP 2000-3300 in Fig. 6; Profile 868: CDP 8500-9400 in Fig. 8). Unconformity U1 has been locally eroded by later discordances (Profile 425: zoom 2 in Fig. 5C; Profile 441: CDP 3300-4000 in Fig. 6; Profile 868: CDP 6900-8500 in Fig. 8 and Profile n-32 in Fig. 9) suggesting that it did extend along the entire shelf. Seismic unit L1 extends along the entire shelf except offshore Manta peninsula and around La Plata island (Fig. 10A). The TWTT isopach map of L1 shows thickness variations between 0.4 to $2.5 \mathrm{~s}$ TWTT. The location of L1 depocenters coincides spatially with the depressed areas previously identified on the TWTT isodepth map of Ub (Fig. 7). In the Central-North segment, the L1 depocenters coincide with the Pedernales, Bahía-Jama and Caráquez depocenters (Fig. 4). In the Central-South segment, NW-trending depocenters coincide with La Plata, Monteverde and Valdivia depocenters.

\subsubsection{Seismic Unit L2}


Seismic unit L2 overlies conformably angular unconformity U1. Parallel seismic configuration with high continuity and amplitude (Profile 433 in Fig. 6) defines the seismic facies of the unit. The L2 reflectors are truncated by paleo-canyons and gullies offshore Cabo Pasado (Profile 433 in Fig. 6), defining disconformity U2 (Profile 433 in Fig. 6; Profile 425: zoom 1 in Fig. 5B and Profile 900: CDP 6800-7500 in Fig. 11). However, southward and northward of Cabo Pasado, disconformity U2 becomes smoother (Profile 425 in Fig. 5A), and shallower near to the coast line ( $<0.4$ s Profiles 441 and 433 in Fig. 6) and deeper further seaward >1.2 s TWTT (Profile 425: zoom 1 in Fig. 5B) and reaches up $2 \mathrm{~s}$ TWTT (Profile 900 in Fig. 11). Seismic unit L2, which has not been recognized along the Central-South segment, extends discontinuously along the North and Central-North segments (Fig. 10B). The TWTT isopach map of L2 (Fig. 10B) shows sharp thickness variations with a maximum thickness of $0.5 \mathrm{~s}$ TWTT and no evidences for remarkable depocenters. The unit thickness variations rather reflect partial to full erosion associated with disconformity U2 or younger ones.

\subsubsection{Seismic Unit L3}

Seismic unit L3 deposited unconformably over L2 and L1b seismic units (Profiles 433 and 900 in Fig. 6 and 11). The seismic facies of unit L3 is thinly stratified with highly variable amplitudes to almost transparent (Profile 900: CDP 6000-7000 in Fig. 11; Profile 425: zoom 1 in Fig. 5B). Its thickness can reach 1.7 s TWTT (Profile 900 in Fig. 11).

Among the discordances imaged within unit L3, prominent unconformity U3 divides the unit into subunits L3a and L3b. This unconformity truncates subunit L3a reflectors and is onlapped by reflectors of subunit L3b (Profile 425, zoom 1: CDP 9000-9200 in Fig. 5B). Subunit L3a shows a divergent configuration with thickness reaching up to $1.3 \mathrm{~s}$ TWTT (Profile 900: CDP 6000-7000 in Fig. 11 and profile 425: CDP 7100-8000 in Fig. 5A). Subunit L3a fills the paleo-canyons of disconformity U2 (Profile 433 in Fig. 6). Subunit L3b shows a maximum thickness of 0.9 s TWTT (Profile 425: CDP 11000-12000 in Fig. 5A). In the Bahía-Jama depocenter, subunit L3b shows a seaward prograding configuration (Profile 900 in Fig. 11). In the Pedernales depocenter, reflectors of seismic units L3, L2 and L1 are truncated by local angular unconformity U4 (Profile 425: zoom 2 in Fig. 5C). Seismic Unit L3 extends only along the North and Central-North segments (Fig. 10C). The TWTT isopach map of L3 (Fig. 10C) shows NNE-trending depocenters in the Bahía-Jama and Pedernales depocenters, although, between the latitudes $0^{\circ} 20^{\prime}$ and $0^{\circ} 29^{\prime} \mathrm{N}$ in the Pedernales basin, L3 was fully eroded by unconformity U4 (Profile 425: CDP 11000-17000 in Fig. 5A). 


\subsubsection{Seismic Unit L4}

Seismic unit L4 lies unconformably over seismic units L1, L2 and L3 through angular unconformity U4 (Profile 425: zoom 2 in Fig. 5C). This seismic unit shows divergent configuration characterized by high continuity, frequency and amplitude (Profile 425: zoom 2 in Fig. 5C). The TWTT isopach map of unit L4 (Fig. 10D) shows a very restricted spatial arrangement in the Pedernales basin (Profile 425: CDP 10900-17000 in Fig. 5A) and shows two depocenters reaching a thickness of $0.6 \mathrm{~s}$ TWTT. The upper boundary of Unit L4 corresponds to regional angular unconformity U5 that extends along the entire margin (Fig. 10E). This unconformity is well defined by local truncations of units L1, L2, L3 and L4 reflectors (Profiles 868, 900, 441 and n-32 in Fig. 8, 11, 6 and 9).

\subsubsection{Seismic Unit L5}

Seismic unit L5 comprises the most recent sediments deposited along the margin. The seismic facies of unit L5 is thinly stratified with variable amplitude to almost transparent. This unit shows two distinct seismic configurations, a divergent configuration beneath the shelf (Profiles 900 and n-32 in Fig. 11 and 9), and a clinoform type configuration across the shelf edge (Profile 1028 in Fig. 13). Regionally, unit L5 rests conformably over angular unconformity U5 (Profile 868 in Fig. 8), however the unit shows downlaps on unconformity U5 (Profile n-32: CDP 2500-2800 in Fig. 9). Thus, seismic unit L5 lies on seismic unit L1 in the Central-South segment (Profiles n-32 in Fig 9), on units L1- L2- L3- L4 in the CentralNorth segment (Profiles 868 and 425 in Fig. 8 and 5), and on unit L3 in the North segment (Profile 1028 in Fig. 12).

The upper boundary of unit L5 is marked by toplaps and truncation of reflectors by the seafloor (Profile 868: CDP 8300-9400 in Fig. 8 and Profile 425: zoom 1 in Fig. 5B).

The TWTT isopach map of unit L5 shows thickness variations between 0.1 and $1 \mathrm{~s}$ TWTT (Fig. 10E). In the Central-North segment two major depocenters are localized in the Pedernales basin and one in the Caráquez basins. In the Central-South Segment, the NE-SW trending La Plata and Valdivia depocenters are recognized.

Across the shelf break and upper slope, unit L5 sediment accumulations are clinoforms constructions as exemplified offshore Manta peninsula (Proust et al., 2016) and in the North segment (Profile 1028 in Fig.12). On the upper margin slope, a L5 depocenter coincides with the Bahía-Jama basin, whereas the others sediments accumulations are slope basins (Martillo, 2016). 


\subsection{Tectonic structures}

\subsubsection{Normal faults}

Faults deform the acoustic basement and seismic unit L1 beneath the inner shelf in the Central-North and Central-South segments (Fig. 7). The faults reach 15 to $50 \mathrm{~km}$ in length. In the Central-North segment, the faults trend E-W and dip southward forming half-grabens offshore Cabo Pasado (Fig. 7). Along strike line 433 (CDP 5500-6000 in Fig. 6), the top of acoustic basement Ub and subunit L1a are vertically offset by $1.5 \mathrm{sec}$ TWTT by a fault along which the hanging wall block has moved down, thus defining a normal fault. Subunit L1a across the fault shows a constant thickness of aprox. 0.6 sec TWTT. On the hanging wall block, subunit L1b shows a fan-like pattern. Subunit L1b is truncated by unconformity U1, and seismic unit L2 seals the fault. These observations indicate that activity of the normal faulting could be restricted within the term of deposition of subunit L1b in the Central-North segment.

In the Central-South segment, the major faults trend NW-SE and dip northeastward offshore Puerto López, forming half-grabens (Fig. 7). Profile n-32 shows the faults (CDP 1400 and 2100 in Fig. 9) to offset vertically unconformity $\mathrm{Ub}$ and subunit L1a by up to $2 \mathrm{sec}$ TWTT. Alike in profile 433 north of Manta, subunit L1b in profile n-32 shows a fan pattern on the hanging wall block of the fault, supporting normal faulting. The sets of normal faults offshore Puerto López and offshore Cabo Pasado were synchronous. However, offshore Puerto López, unconformity U5 truncates L1b strata and seismic units L2 to L4 were not recognized. Seismic unit L5 seals the deformation due to the normal faults in the Central-South segment.

\subsubsection{The Bahía-Jama strike slip fault system}

Offshore Bahía de Caráquez, a set of NE-trending faults was interpreted as a transtensional fault system by Collot et al., (2004). This fault system bounds a NE elongated depression of the acoustic basement that hosts the Bahía-Jama depocenter (Fig. 4 and 7). Profile 900 (CDP 5000 -6000 in Fig. 11) images a flower structure that consists of three main fault branches that deform the acoustic basement and the overlying sedimentary units. There are several evidences to constrain the term of this strike-slip fault system. Firstly, the greatest thickness, up to $1 \mathrm{~s}$ TWTT, of subunit L3a is recorded inside the fault system (Profile 900: CDP 5600 to 6000 in Fig. 11). Secondly, subunit L3b increases its thickness seaward and show small fan patterns against the central and occidental fault branches (CDP: 5500 to 5800 in Fig. 11). Thirdly, reflectors within subunits L3a and L3b abut seaward against the upper 
part of the oriental fault branch through a complex pattern that has evolved over time from an east- to a west-dipping configuration (CDP 5900 to 6100 in Fig. 11). Finally, the vertical offset of unconformity U5 and the development of the fan patterns of seismic unit L5 related to the central and occidental fault branches (CDP 5300 to 5600 in Fig. 11). These observations indicate that a fault-controlled subsidence and syn-sedimentation strike-slip deformation was active during deposition of subunits L3a and L3b. The sediment thickness might be locally controlled by the activity of the central and occidental fault branches. The fault activity could be still active during the deposition of unit L5, and may still affect the seafloor topography.

\subsubsection{The Manta anticline}

Offshore Manta peninsula, the TWTT isodepth map of Ub shows a narrow $(15 \mathrm{~km})$ structural high extending northward for $\sim 40 \mathrm{~km}$ (Fig. 7). Seismic line 868 (Fig. 8) shows the faulted acoustic basement and overlying seismic units L1 and L2 to have been jointly deformed, forming the Manta anticline. Across both limbs of the anticline, units L1 and L2 were truncated by unconformity U5 and by seafloor at its apex. The growth of the anticline culminated after the tilt of unit L2 across both limbs of the anticline, and prior to unit L3 deposition as indicated by unit L3 strata on lapping angular unconformity U2 on the western limb of the anticline (Profile 868: CDP 6500, Fig. 8). The apparent non-deposition of L5 over the anticline and the $\sim 0.2 \mathrm{~s}$ TWTT thin L5 depocenters beneath the inner and outer shelf, together with the truncation of unit $L 5$ reflectors against the seafloor suggest that the anticline is still active.

\subsubsection{The Cabo Pasado anticline}

Offshore Cabo Pasado, the TWTT isopach map of L3 shows an E-W-trending structural high, which separates two depocenters (Fig. 10C). Seismic line 425 (zoom 1 in Fig. 5B) shows the structural high to be involved in a gentle anticline affecting overlying seismic units. The northern limb of the anticline is deformed by a north-dipping normal fault associated to minor antithetical faults. In zoom 1 (Profile 425, CDP 9000-9800 in Fig. 5A) a secondary unconformity divides subunit L3a into lower and upper sections. The thickness of the Lower L3a section is maximum (0.5 s TWTT) on the crest of the anticline (zoom1: CDP 9000-9800 in Fig. 5B) and decreases towards the anticline limbs, where reflectors of lower L3a section downlap apparently onto unconformity U2. Moreover, although the deposits of the upper section of L3a are partly eroded by unconformity U3, they thicken away from the 
anticline apex, and their reflectors show different dips . Reflectors of subunit L3a and 5 show a bulging configuration. . The development of the anticline continues during subunit L3b and unit L5 deposition as evidenced by the bulging configuration of their reflectors. Unconformity U5 and unit L5 reflectors are truncated at the seafloor (Zoom1 CDP 92009600, Fig. 5B). These detailed observations indicate that a former depocenter structurally inverted during the anticline formation, which likely occurred during sedimentation of upper subunit L3a and continued until deposition of unit L5 or even recent.

\subsubsection{The Pedernales structural high}

Northwest of Pedernales, an E-W trending structural basement high underlies the shelf (Fig. 7 and 10C). Zoom 2 of seismic profile 425 (Fig. 5C) shows an acoustic basement high spatially associated with a noticeable basement rise from the Central-North segment toward the north. At this location, seismic units L1 and L2 (zoom 2, CDP 16200-16700, Fig. 5C) show evidence for tilting and folding. Immediately to the south of this structural high, unconformity U4 truncates the reflectors of seismic units L1, L2 and L3a, while unconformity $\mathrm{U} 4$ becomes concordant with the reflectors of the wedge-shaped termination of subunit L3b (zoom 2, CDP 15000-15500, Fig. 5C). The depocenter of unit L4 trends E-W direction (Fig. 10D) and seismic configuration of units L4 and L5 diverges along profile 425. Shallow unconformity U5 truncates seismic units L2 to L4, across the L4 depocenter. These evidences indicate that compressive deformation and uplift of units L1 and L2 synchronously with unconformity $\mathrm{U} 2$ occurred during the deposition of unit L3b and prior to a local erosion by angular unconformity U4. The location of the depocenter of unit L4 indicates that local subsidence ensued on and directly south of the Pedernales structural high, pointing to a local topographic inversion, from uplift to subsidence of the Pedernales structural high. Shallow unconformity U5 truncates seismic units L2 to L4, across the L4 depocenter, supporting a last deformation stage related to the development of the Pedernales structural high .

\section{Discussion}

5.1. Dating the offshore forearc basin seismic units and their bounding unconformities

The seismic units and their bounding unconformities are tentatively dated (Fig. 13) by correlating interpreted seismic profiles 441 (Fig. 6) and n-30 (Fig. 9) with the geological Formations identified in the offshore Caráquez-1 (Quintana Petroleum Corp., 1971 
unpublished report; Hernández, 2012) and Montañita-1 wells (Belco Petroleum Ecuador Inc. 1988, unpublished report) and in the onshore Manta-5 well (Fig. 2) (Benítez, 1995). The proposed ages of the seismic units are substantiated by their comparison with onshore chronostratigraphic charts of the Santa Elena peninsula, and the Manabí and Borbón basins (Fig. 3).

\subsubsection{Acoustic Basement: Piñón and Cayo Formations (late Cretaceous)}

The top of the acoustic basement correlates either with the top of the Cretaceous Piñón Formation (Fig. 3) sampled in the Manta-5 well (Fig. 13) or with the top of the late Cretaceous Cayo Formation (Fig. 3) identified in the Caráquez-1 and Montañita-1 wells (Fig 6 and 9). The Piñón Formation is overlain by the volcano-clastic Cayo Formation (Fig. 3) (Benítez, 1995; Luzieux et al., 2006; Jaillard et al., 2009). Considering the entire study area, any of these Formations may compose the top of the acoustic basement.

\subsubsection{Seismic Subunit L1a: Zapallo, San Mateo Formations and Ancón Group (middle to late Eocene)}

Subunit L1a is correlated with the Zapallo Formation in the Caráquez-1 well, the San Mateo Formation in the Manta-5 well, and the Ancón Group in the Montañita-1 well (Fig. 6, 9 and 13). According to Benítez, (1995) these three middle to late Eocene Formations are lateral equivalents of each other (Fig. 3), and were deposited in a shelf to upper slope environment (Ordóñez et al, 2006). The sedimentary Ancón Group identified in the Santa Elena peninsula reaches thicknesses up to 1900 m (Bristow et Hoffstetter, 1977; Reyes 2013). The sedimentary San Mateo Formation outcrops in the Manta peninsula, reaching thicknesses between 400 and $700 \mathrm{~m}$ (Bristow et Hoffstetter, 1977; Reyes 2013). The Zapallo Formation in the region of Esmeraldas comprises 500 to $1000 \mathrm{~m}$ of clastic sediment (Evans and Whittaker, 1982; Reyes, 2013; Bristow and Hoffstetter, 1977). The $0.4-0.8$ s TWTT thickness of unit L1a is compatible with the average thickness of the San Mateo and Zapallo Formations in the onshore forearc basins. Onshore, the Ancón Group, and the Zapallo and San Mateo Formations are underlain by the thin calcareous Santiago, Ostiones and San Eduardo Formations (Fig. 3; Evans and Whittaker, 1982, Reyes, 2013; Bristow and Hoffstetter, 1977). Offshore, the San Eduardo Formation was sampled in the Caráquez-1 well (Fig. 6 and 13). Due to the high acoustic impedance of the carbonate, the $0.1 \mathrm{~s}$ TWTT -thick reflectors overlying Ub unconformity may include thin (100-150 m thick) calcareous beds (Fig. 6). 


\subsubsection{Seismic Subunit L1b: Playa Rica / Pambil Formations and Tosagua Group (Oligocene- early middle Miocene)}

Offshore Bahía de Caráquez, subunit L1b tentatively correlates with the Oligocene Playa Rica/Pambil Formations and early middle Miocene Tosagua Group sampled in the Caráquez-1 and Manta-5 wells (Fig. 6 and 13). The Tosagua Group was first considered as a whole with the Playa Rica and Pambil Formations, before Benítez (1995) separated the Tosagua Group as only Miocene in age and Playa Rica/Pambil Formations as only Oligocene in age. Oligo-Miocene shales and silty shales, sampled in Manta-5 well (Fig. 6 and 13) (Benítez, 1995) are then correlated with the shales in the Caráquez-1 well (between 1347 to $600 \mathrm{~m}$ of depth in Fig. 13), which correspond to the Playa Rica Formation and Tosagua Group. Regional unconformity U0 that tops subunit L1a may coincide with the sedimentary hiatus dated 41-32 Ma in the Progreso basin (Witt et al., 2019).

The Tosagua Group overlies regionally the Playa Rica and Pambil Formations after a hiatus dated from the Oligocene-Miocene boundary (Fig. 3) (Benítez, 1995). The hiatus was not recognized on the studied seismic profiles, possibly because the onshore geological facies of these Formations and Group are very similar and cannot be distinguished on the offshore seismic profiles. In contrast, this hiatus is well defined in the Manglares basin (Fig. 3; unconformity U3 of Marcaillou and Collot, 2008; Collot et al., 2019). Sediments of these Formations and Group deposited in a bathyal environment (Evans and Whittaker, 1982), and evolved upward in the Group toward shallow water deposits (Benítez, 1995; Ordóñez et al., 2006). The Playa Rica Formation is 600m thick (Benítez, 1995) and the Pambil Formation is up to $1000 \mathrm{~m}$ thick in the Borbón basin (Evans and Whittaker, 1982). The Tosagua Group comprises the Dos Bocas, Viche and Villingota clastic Formations (Deniaud, 2000; Reyes, 2013).

At the base of the Tosagua Group, the Dos Bocas Formation is a 2.5 to 3-km-thick. The Viche Formation in the Borbón basin is a lateral equivalent of the Dos Bocas Formation, and is $\sim 1-\mathrm{km}$ thick. Overlying both Formations, the Villingota Formation is 300 to $600 \mathrm{~m}$ thick (Reyes, 2013). The total thickness of the Playa Rica/Pambil Formations and Tosagua Group is consistent with that of subunit L1b that reaches up to $1.5 \mathrm{~s}$ TWTT.

\subsubsection{Seismic Unit L2: Angostura - Lower Onzole Formation (middle - late Miocene)}

Seismic unit L2 correlates with the middle to late Miocene Angostura and Lower Onzole Formations sampled in the Caráquez-1 well (Fig. 6 and 13). Both the Angostura and the Lower Onzole Formations were dominantly deposited in a shelf environment (Benítez, 
1995; Ordonez, 2006). In the Caráquez-1 well, a sequence of shale and sandstone with conglomerate was recovered between 600 and $134 \mathrm{~m}$ of depth and attributed to the Angostura Formation (Quintana Petroleum Corp., 1971 unpublished report, Fig. 13). This interpretation would imply that units L2 and L3a (Fig. 6 and 13) belong to the Angostura Formation. However, in our new interpretation of the well, the change in lithology at a depth of $469 \mathrm{~m}$ coincides with unconformity U2 (Fig. 6 and 13), leading to correlate the Angostura and Lower Onzole Formations with seismic unit L2. Moreover, unconformity U2 correlates with a major onshore late Miocene - early Pliocene erosive unconformity that separates the lower Onzole Formation from the overlying Lower Borbón Formation (Reyes, 2013), (Fig. 3). However, because the Lower Onzole Formation overlies the Angostura Formation in transitional contact, they cannot be distinguished within unit L2. Angular unconformity U1 is identified in the Caráquez-1 well by a sharp contact between shale and overlying sandstones/conglomerates at a $600 \mathrm{~m}$ depth (Fig. 13). This unconformity correlates with the regional, 14-12 Ma-old, angular unconformity associated with the sedimentary hiatus between the Angostura and Tosagua Formations reported onshore (Fig. 3, Deniaud, 2000; Reyes, 2013; Bristow and Hoffstetter, 1977) and offshore in the Manglares basin (Marcaillou and Collot, 2008; López, 2009).

\subsubsection{Subunit L3a: Lower Borbón member (early Pliocene)}

Subunit L3a deposited over late Miocene - early Pliocene unconformity U2, tops the Lower Onzole Formation. Therefore, we propose to correlate subunit L3a with the Lower Borbón Member that is dated early Pliocene (Reyes, 2013) (Fig. 3 and 6). In subunit L3a, the Caráquez-1 well recovered an alternation of shale and sandstone between 134 to $469 \mathrm{~m}$ of depth (Fig.13). This lithology fits with the coarse-to-fine-grained sediment of the 250-400mthick, Lower Borbón Member (Reyes, 2013) (Fig. 3).

\subsubsection{Subunit L3b: Middle Borbón member (late Pliocene - earliest Pleistocene)}

Seismic subunit L3b was not sampled in the Caráquez-1 well (Fig. 13). According to its chronostratigraphic position and that of its bounding unconformities U3 and U4/U5, subunit L3b is tentatively correlated with the Middle Borbón Member that is also bounded onshore by marked unconformities (Reyes, 2013) (Fig. 3).

\subsubsection{Units L4 and L5: Upper Borbón member (Pleistocene)}


According to their stratigraphic position, units L4 and L5 are correlated with the Upper Borbón Member that is dated Pleistocene (Fig. 3; Di Celma et al., 2002; Reyes, 2013). In the Caráquez-1 well, unit L5, which rests above unconformity U5, is correlated along profile 441 (Fig. 6) with less than $100 \mathrm{~m}$ thick of coarse-grained sediments (Fig. 13). This lithology is close to that of the volcano-clastic sediment of the Upper Borbón Member (Reyes, 2013) although the volcanic component of the Formation was not reported in the Caráquez-1 well. Unconformity U5 extends along the entire margin and cuts across most of the older seismic units (Fig. 5A). Analogously, the unconformity that underlies the Upper Borbón Member onshore cuts locally older Formations down to the Onzole and Angostura Formations and possibly deeper (Reyes, 2013) thus supporting the correlation between unit L5 and the Upper Borbón Member. In the Manta area (Fig. 5A), seismic unit L5 was dated late Pleistocene by calibration with the eustatic curve (Proust et al., 2016). Therefore, an late Pleistocene age is inferred for this unit all along the margin.

\subsection{The margin segments and their transition zones}

\subsubsection{The margin segments}

The TWTT isodepth map of Ub (Fig. 7) together with TWTT isopach map of the entire sedimentary fill comprised between $\mathrm{Ub}$ and seafloor (Fig. 4) evidence the structural segmentation suggested from the FAA analysis (Fig. 2). The North segment is identified by a shallow acoustic basement ( $~ 0.5 \mathrm{~s}$ TWTT depth), the seismic units L1 to L5 except unit L4 represent its sedimentary fill which is located mostly in the outer shelf. The Central-North segment is recognized by a deep acoustic basement reaching $\sim 2.7 \mathrm{~s}$ TWTT of depth where Pedernales, Bahía-Jama and Caráquez forearc sedimentary depocenters are located. This segment was affected by Oligo-Miocene normal faulting and Pliocene strike-slip faulting. Like the North segment, the Central-South segment is characterized by a shallow acoustic basement ( $0.5 \mathrm{~s}$ TWTT depth). However, in the Central-South segment, the youngest seismic unit L5 overlies the oldest unit L1. This segment was affected by the Oligo-Miocene normal faults that controlled the development of the La Plata and Monteverde depocenters and were synchronous to normal faults, described in the Central-North segment. The variability between each segment and the diversity of tectonic structures show that the deformation is not homogeneous along the margin. Areas where the deformation is concentrated as the Manta anticline, Pedernales structural high and Bahía-Jama strike-slip fault system are located in the transition zones between the margin segments. These 
intersegment transition zones discussed below, reveal the timing of the forearc segmentation and the role of the forearc structural heritage.

\subsubsection{The intersegment transition zones}

The Pedernales structural high outlines the transition zone between the North and the Central-North segments (Fig. 7). In this area, the TWTT isopach map of unit L3 (Fig. 10C) shows an interruption of Pliocene L3 depocenter continuity caused by the emplacement of the Pedernales structural high. The uplift of the acoustic basement, which accompanied the development of the Pedernales structural high, was synchronous with seismic subunit L3b deposition evidencing the individualization between North and Central-North segments during the late Pliocene - earliest Pleistocene. The North segment began to individualize by uplift during the late Pliocene deposition of unit L3b up to the vigorous erosion of the Pedernales structural high during unconformity U4 that occurred at the Pliocene-Pleistocene boundary, marking the full individualization of the North segment from the Central-North segment.

The Manta anticline and Bahía-Jama strike slip fault system outline the transition zone between the Central-North and Central-South segments. TWTT isopach map of unit L1 (Fig. 10A) extends along the entire margin, while unit L2 (TWTT isopach map of L2 in Fig. 10B) is presently restricted to the Central-North and North segments. The lack of unit L2 in the Central-South segment can be explained according to two hypotheses: 1) seismic unit L2 deposited along the non-segmented entire margin prior to be deformed and eroded in the Central-South segment during its uplift, or 2) the individualization of the Central-North and Central-South segments occurred before unit L2 was deposited in the Central-North segment. The Manta anticline in the transition zone between the two segments, shows that seismic unit L2 was folded, uplifted and partially eroded prior to L3 deposition, likely in response to the uplift and individualization of the Central-South segment at the Miocene-Pliocene boundary, thus supporting hypothesis 1 .

The most important structural boundary between the Central-North and Central-South segments might be the Bahía-Jama strike slip fault system that developed at least during unit L3 deposition (Fig. 10C and 11). Nevertheless, the tectonic activity of the fault system might have initiated earlier, although such pre-L3 deposition activity cannot be demonstrated because seismic units older than unit L3 were strongly deformed and eroded in the transition zone (Fig. 11). 


\subsubsection{The upper plate structural heritage and the margin segmentation}

The forearc domain and Western Cordillera are composed by a mosaic of tectonostratigraphic blocks of oceanic origin, which are bounded by major faults (Jaillard et al., 1995; 1997; 2009; Luzieux et al., 2006). These inherited structures can be reactivated at the favor of plate reorganization such as along the North Andean Sliver eastern boundary (Alvarado et al. 2016). North of Ecuador, the structural limit between the Desgracia and Naranjal blocks in the Western Cordillera trends NNE (Luzieux et al., 2006) and connects westward with the ENE-trending Canandé fault (Fig. 1; Reyes and Michaud, 2012). The Canandé fault separates the Borbón basin to the north from the Manabí basin to the south (Reyes, 2013; Deniaud, 2000) (Fig. 1), and is identified with an elongated positive ENEtrending FAA that can be followed up to the coastal area (Fig. 2). This FAA is associated with an ENE-trending basement high (Fig. 1) evidenced by outcrops of the Piñon Formation (Fig. 2, Reyes and Michaud, 2012). The offshore projection of the basement high coincides with the Pedernales structural high suggesting a structural continuity. Therefore, both the FAA and onshore geological data provide evidences for the onshore-offshore regional prolongation of the transition zone between the North and the Central-North segments. This inherited structure was reactivated during the late Pliocene and is responsible for the North segment individualization.

The NE-trending Jama fault system (Fig. 1; Reyes and Michaud, 2012) is interpreted as the eastern structural limit of Pedernales-Esmeraldas block (Luzieux et al., 2006), active from the early Paleogene - Neogene times (Deniaud, 2000) to the Pleistocene (Reyes et al., 2018). The Jama fault system is collinear with a NE-trending positive FAA (Fig. 2) where the geological basement of Piñón Formation crops out (Fig. 1). The offshore prolongation of the Jama fault system coincides with the transition zone between the Central-North and CentralSouth segments (Fig. 7). This observation suggests that the inherited boundary between the Pedernales-Esmeraldas and San Lorenzo blocks (Luzieux et al., 2006; Fig. 15A) could extend southwestward offshore and could have help to localize the offshore boundary zone between the Central-North and Central-South segments through crustal fault re-activation. The offshore transition zone is associated with the NE-trending crustal strike-slip fault imaged by Collot et al. (2004). This fault is, however, offset northward with respect to the seaward projection of the Jama fault, suggesting that the offshore transition zone between the margin segments consists of en-echelon fault segments. Although the two fault systems may have developed on a single inherited structure, the offshore strike-slip fault system terminates on 
Cabo Pasado anticline (Fig. 10C) in the form of a single restraining bend (Cunningham and Mann, 2007). Although the individualization of the Central-North and Central-South segments occurred at the Miocene-Pliocene boundary during the Manta anticline formation, the reactivation of the inherited Jama fault structure during the Pliocene contributed to enlarging the transition zone. The NW-trending, Oligo-Miocene normal faults in the CentralSouth segment are collinear with the onshore Colonche and La Cruz crustal faults, which bound the Pinon and Santa Elena blocks (Fig. 1, 4 and 15A) and coincide with a steep NWtrending FAA gravity gradient (Fig. 2). This geometry suggests that the offshore NWtrending normal faults are inherited.

\subsection{Structural evolution of the Ecuador Offshore forearc}

The distribution of forearc basin seismic units and unconformities together with the analysis of tectonic structures, allows identifying several deformation and sedimentation stages to propose a reconstitution of the main events related to the evolution of the Ecuadorian offshore forearc basin:

1- In the study area, between Santa Elena peninsula and Esmeraldas the initial sedimentation stage occurred in the form of a single forearc basin represented by middle to late Eocene sediments of subunit L1a that deposited unconformably over the oceanic acoustic basement. This sedimentation stage is interpreted to have occurred onshore in an extensional regime (Jaillard et al., 1997). At the top of subunit L1a, regional unconformity U0, dated 4132 Ma by Witt et al. (2019) coincides with a regional uplift, thus preparing for the formation of the modern, i. e. post Eocene forearc basins (Jaillard et al., 1995, Benitez, 1995; Witt et al., 2019; Aizprua et al., 2019).

2- The normal faults that controlled the sedimentation of subunit L1b during the Oligocene to early middle Miocene ( 30-14-Ma) support a stage of extensional deformation, which may have been contemporaneous with the split of the Farallon plate (Figs. 7 and 15A). Prior to $28 \mathrm{Ma}$ the strongly oblique subduction of the Farallon plate (Somoza and Ghidella, 2012) beneath the Ecuador margin possibly initiated a trench-parallel stretching and normal faulting of the forearc within a regional strike-slip framework. Some $28-25 \mathrm{Ma}$ ago, the convergence obliquity decreased and the convergence rate increased (Somoza and Guidella, 2012). Synchronously, the subducting Farallon plate started to stretch and rift in a $\sim$ NS direction (Lonsdale, 2005) generating seafloor roughness as suggested by the Alvarado and Sarmiento ridges (Lonsdale, 2005). The oblique subduction of the topographically rough 
plate contributed to enhancing the interplate coupling, and renewed trench-parallel extension across pre-existing forearc normal faults. Although, the Coco-Nazca spreading center initiated 23 Ma (Lonsdale, 2005), the old rifted Farallon plate probably kept subducting until $\sim 14 \mathrm{Ma}$ beneath the Ecuador margin while the convergence rate decreased (Meschede and Barckhausen, 2001).

3- The early middle Miocene ( 14-12 Ma) uplift stage associated with angular unconformity $\mathrm{U} 1$ and with a shallowing of the sedimentation of seismic unit L2 with respect to unit L1 was identified beneath the northern Ecuador shelf and upper margin slope (Collot et al., 2019). This stage possibly coincides with the early stages of subduction of the Nazca plate. At $14 \mathrm{Ma}$, the Nazca plate born $23 \mathrm{Ma}$ ago, was very young ( 10 Ma old) and hot (Meschede and Barckhausen 2001) suggesting that an elevated topography entered progressively the subduction in Ecuador, generating a major uplift phase as already proposed for the SW margin of Colombia by Lopez-Ramos, (2009). The subduction of this young lithosphere might additionally have lowered the slab dip. Low slab dip has been shown to correlate with back-arc upper plate compression (Lallemand et al., 2005) suggesting that low slab dip may also produce contraction and uplift of the margin forearc domain. In addition to the geodynamic cause of unconformity U1, the global lowering of the sea level that followed the Miocene Climatic Optimal (Hansen et al., 2013; Fig. 14), might have contributed to shape this unconformity.

4- The early Pliocene ( $5.2 \mathrm{Ma})$ deformation stage is associated with the individualization and uplift of the Central-South segment as well as with the incision and erosion of seismic unit L2 by unconformity U2. This stage occurred during a period of sea level lowering between 5.5-4.9 Ma (Miller et al., 2005). However, this deformation stage is tentatively correlated with the arrival in the subduction of the Carnegie ridge as proposed by Collot et al., (2019) to account for an increase of the margin uplift along the southern flank of the Manglares basin. Since the Mio-Pliocene boundary, the Coastal Cordillera and onshore forearc basins recorded a cooling period associated with a 1-km uplift (Brichau et al., 2019). Contemporarily, in the Western and North-Eastern Cordilleras of the Ecuadorian Andes a pulse of elevated exhumation initiated at 5.5 Ma (Spikings et al., 2010). These exhumation events were attributed by these authors to the subduction of Carnegie ridge, the initial phase of which may have occurred $\sim 5 \mathrm{Ma}$ ago according to the model proposed by Collot et al. (2009). 
Offshore, the margin uplift pattern is segmented as it consists of the uplifting CentralSouth segment, while the Central-North segment appears to subside. The gullies and paleocanyon that incised seismic unit L2 offshore Cabo Pasado (Fig. 15B) support a paleo-slope increase that is coherent with a seaward tilt of the margin seafloor, an uplift of the adjacent Coastal Range and the inception of the Esmeraldas Canyon 5 Myr ago (Collot et al., 2019). In a simple kinematic model (Fig. 15B), the subsidence of the Central-North segment appears to correlate spatially with the subduction of the Carnegie ridge topography (Fig. 15B), and could have been caused by subduction erosion as proposed for the central Peruvian margin in response to the Nazca ridge subduction (Hampel et al., JGR, 2004). In contrast, the cause of the Central-South segment uplift remains puzzling. Although the morphology and crustal structure of the subducted part of the Carnegie ridge are unknown, several hypotheses can be considered: 1) underplating of thrust slices of the young Nazca plate, 2) subduction of the Carnegie ridge could have affected a wider region of the forearc than its footprint on the subducting plate, involving the Central-South segment, and 3) the southward creep of the ridge along the trench could have uplifted the Central-South segment southward of the ridge trench junction as exemplified in the case of the Louisville ridge along the Kermadec trench (Funnell et al., 2014).

5- The Pliocene - early Pleistocene seismic unit L3 recorded the subsidence of the Central-North segment, the deformation associated with the strike-slip activity in the BahíaJama depocenter area, and the individualization by uplift of the North segment (Fig. 15C). This deformation stage coincides with the acceleration of the northeastward migration of the North Andean Sliver (Deniaud, 2000; Witt et al., 2006). According to Collot et al., (2009), from $\sim 2 \mathrm{Ma}$ on, the area of the subducted Carnegie ridge along the inter-plate contact could have been large enough to create the necessary frictional conditions to favor the escape of the NAS along its eastern boundary. Under these conditions, the offshore extensions of the Jama and Canandé faults, could have been dominantly reactivated by strike-slip and contraction, respectively.

6- The mosaic of middle to late Pleistocene unit L5 depocenters that alternate along the entire shelf with uplifted zones recorded (Fig. 15D) a contractional deformation, the wavelength of which reflects the structural grain of the Carnegie ridge. As an example, in the Central-South segment, a subducting oceanic relief produced a permanent flexural bulge, which uplifted the La Plata island (Collot et al., 2017) and created an adjacent shelf 
depression filled with middle- late Pleistocene sediments of the La Plata basin (Proust et al., 2016). Indeed, in the Central South segment, none of the NE-trending depocenters are controlled by major fault, i. e. they rather feature crustal downwarp in contrast with the NWtrending, fault-controlled, Oligo-Miocene half grabens that likely developed from inherited faults. The subduction of the topographically irregular Carnegie ridge, probably contributed to promoting the heterogeneous and short-wavelength uplift/subsidence pattern of the offshore forearc basin during the middle to late Pleistocene.

\section{Conclusions}

This work has allowed evidencing the main stages of evolution of the offshore Ecuadorian forearc basin that set up on accreted oceanic terranes. The interplay between subduction, margin inherited structures and regional geodynamic processes is proposed to have controlled the sedimentary and tectonic evolution of the basin, which in turn recorded the segmentation of the margin into Central-South, Central-North- and North segments. The modern offshore forearc basins began individualization in response to $\sim \mathrm{NS}$ tectonic extension that affected the margin during the Oligocene to early middle Miocene ( 30-14-Ma). This extension initiated during the rifting and oblique subduction of the Farallon plate beneath the Ecuador margin ( 30-23 Ma). The regional early middle Miocene ( 14-12 Ma) uplift of the offshore forearc basins is potentially associated with the arrival in the subduction of the young and warm Nazca plate, in a less oblique plate convergence regime. During the early Pliocene ( 5.2 Ma), the individualization and uplift of the Central-South margin segment, which is coeval with the formation of the NS-trending Manta anticline, is tentatively associated with the arrival of the Carnegie ridge in the subduction. The individualization and uplift of the North margin segment occurred during the Pliocene-early Pleistocene, synchronously with a reactivation of the Canandé fault system. At about the same time, strike-slip tectonics in the Bahía-Jama depocenter area may coincide with a reactivation of the Jama fault system and the northward migration of the North Andean Sliver.

Finally, since the middle to late Pleistocene, during the current stage of margin erosion, the short-wavelength uplift/subsidence pattern that characterizes the modern shelf would be dominantly related with the contraction and associated flexural deformation induced by the subduction of the topographically irregular Carnegie ridge. As a conclusion, this study tends to demonstrate that the Neogene to Pleistocene evolution of the Ecuador offshore fore-arc basin was rather controlled by basement vertical motions, faulting, folding and local 
flexuring, than by the growth of a seaward bounding structural ridge that would have trapped the sediment derived from the continent. Moreover, because the margin was progressively eroded over time, the shelf fore-arc basin was getting closer to the plate interface and was increasingly influenced by its topography and physical properties. These processes appear to account for sediment entrapment along a nonaccretionary-type forearc basin.

Acknowledgments: M-J Hernández acknowledges support provided by the Secretaría de Educación Superior, Ciencia, Tecnología e Innovacion (SENESCYT), the Escuela Politécnica Nacional de Quito (EPN) through a $\mathrm{PhD}$ grant. Schlumberger is thanked for offering the use of Petrel ${ }^{\mathrm{TM}}$ software. This work was funded by the Institut de Recherche pour le Développement (IRD) and the Institut National des Sciences de l'Univers (INSU). It was carried out in the frame of the Proyecto Interno PII-DG-001-2015 (VIPS-EPN) and Joint French-Ecuador Laboratory "Earthquakes and Volcanoes in the Northern Andes". We acknowledge support from IRD/ANR REMAKE program (ANR-15-CE04-0004) and UCA/JEDI project (ANR-15-IDEX-01). We also acknowledge support from IRD/ANR MARACAS program (ANR-18-CE31-0022). We acknowledge Dr. Paulatto Michele (Faculty of Engineering, Department of Earth Science \& Engineering, Imperial College London) for the realization of the gravity FAA grid. We acknowledge Diego Barba and the PDVSA team in Ecuador for their help in the data analysis. We are grateful to the Secretaría de Hidrocarburos del Ecuador (SHE) for providing us with seismic sections from the SCAN2009 seismic experiment within the framework of the SHE-EPN-EPN tech EP and of the SHE-IRD cooperation agreement. Requirement for SCAN-2009 seismic data can be addressed to Dirección de Análisis de Información Estratégica de Hidrocarburos Av República de El Salvador N36-64 y Suecia, Quito 170135. Edificio MSP. Piso 5, Ecuador (https://www.recursosyenergia.gob.ec/viceministerio-de-hidrocarburos). We thank E. Jaillard for his help and his suggestions. We thank A. Noda and C. Witt for their constructive comments.

\section{Figure captions}


Figure 1: A) Geodynamic framework from Gutscher et al. (1999), plate convergence between Nazca and South-American plates from Trenkamp et al. (2002). B) Simplified geologic framework after Reyes and Michaud (2012) and bathymetry from Michaud et al. (2006). Thick black arrow is relative convergence between Nazca plate and North Andean Sliver from Nocquet et al. (2014). Gray areas are oceanic crustal blocks from Luzieux et al. (2006) and from Aizprua et al. (2019) for the Santa Elena high. Onshore regional faults are from Reyes and Michaud (2012) and offshore faults in the gulf of Guayaquil are from Witt et al. (2006). Green areas are outcrops of the Piñón and Cayo Formations from Reyes and Michaud (2012). Dotted blue lines are the boundaries of the forearc basins: Manabí, Progresso, Valdivia and Manta-Bahía from Deniaud (2000); Borbón and Manglares from Collot et al. (2019), and gulf of Guayaquil basin from Aizprua et al. (2019).

Figure 2: Gravity Free Air Anomaly (FAA) map from Satellite Altimetry (in pale colors from Sandwell et al., 2014) merged with higher resolution aerogravimetric data (in dark colors from Sander Geophysics Limited, 2011). Grid size of $450 \mathrm{~m}$ and contours every $5 \mathrm{mGal}$. White contour is the $-150 \mathrm{~m}$ isobath associated to the continental shelf break. Thin blue lines are SCAN industrial seismic reflection profiles; thick blue lines are the seismic profiles shown in this work. The letters are the FAA described in the text.

Figure 3: Correlation between offshore forearc basin seismic units L1 to L5 and unconformities Ub to U5 with onshore Geological Formations. Chronostratigraphic charts of the Santa Elena peninsula representing the Central-South segment, and the Manabí/Borbón basins representing the Central-North and North segments respectively. Pre-Oligocene chronostratigraphy is from (1) Jaillard et al. (1995 and 1997); the Neogene chronostratigraphy is from (2) Deniaud (2000), (3) Marcaillou and Collot (2008) and (4) Reyes (2013). The Chronostratigraphic chart of the Manglares basin is from Marcaillou and Collot (2008) and Collot et al. (2019).

Figure 4: TWTT isopach map of the forearc basin sedimentary fill (L1 to L5 seismic units); contour lines each $250 \mathrm{~ms}$. Bathymetric map from Michaud et al. (2006) with grey contours each $500 \mathrm{~m}$. White contour is the $-150 \mathrm{~m}$ isobath. Straight thin lines are seismic data used to contour the map. Black lines are offshore regional faults and tick marks indicate their dip. Onshore faults are from Reyes and Michaud, (2012). Red arrows are axis of the main structural highs. White dotted lines delineate the offshore depocenters. 
Figure 5: Seismic profile 425 (Vertical Exaggeration: $V E=4$ ) shows the distribution of the margin segments and their associated forearc depocenters. $\mathrm{CDP}=\mathrm{Common}$ Depth Point. Location on Figure 2. A) L1 to L5 are seismic units and Ub to U5 are regional unconformities. Red lines are faults. Note that the acoustic basement top (Ub) is deep (2-2.5 stwtt) in the Central-North segment and shallower in the Central-South (0.5 stwtt) and North (1.5 stwtt) segments. B) Zoom 1 shows structure of the Cabo Pasado anticline. C) Zoom 2 shows the contractional zone associated with the Pedernales structural high, which top has been truncated by unconformity U4 beneath the Pedernales depocenter.

Figure 6: Seismic profiles 441 across the Caráquez depocenter and 433 across the Pedernales depocenter $(\mathrm{VE}=4)$. Location on Figure 2. L1 to L5 and Ub to U5 as in Fig 5. A) Seismic profile 441 showing the correlation between seismic units and the Geological Formations identified in the Caráquez-1 and Manta-5 wells. B) Seismic profile 433 showing a major normal fault deforming the basement and unit L1, sealed by unconformity U1. Paleo-canyons and gullies incise seismic unit L2 along unconformity U2.

Figure 7: TWTT isodepth map of the top of the acoustic basement (Ub), contour lines each 200ms. Black lines are faults onshore and offshore, red arrow represent the axis of the Manta anticline (N-S) and Pedernales structural high (E-W). Bathymetric map from Michaud et al. (2006) with grey contours each $500 \mathrm{~m}$. Straight thin lines are the seismic profiles used to contour the map. Onshore faults are from Reyes and Michaud (2012).

Figure 8: Seismic profile 868 across the Manta anticline, Bahía-Jama and Caráquez depocenters (VE $=4)$. Location on Figure 2. L1 to L5 and Ub to U5 as in Fig 5. The structural high of Ub represents the Manta anticline. The growth of the Manta anticline culminated after the tilt of seismic unit L2, and prior to unit L3 deposition which strata onlap angular unconformity $\mathrm{U} 2$ on the western limb of the anticline.

Figure 9: Seismic profiles n-32 and n-30 along the Central-South margin segment (VE x4). Location on Figure 2. L1 to L5 and Ub to U5 as in Fig 5. A) Seismic profile n-32 shows North-dipping normal faults controlling the La Plata depocenter. The La Plata island and Manta peninsula are projected. B) Seismic profile n-30 shows the structure beneath the Valdivia and Monteverde depocenters. Montañita-1 offshore well is projected. 
Figure 10: TWTT isopach maps of seismic units L1 to L5. White contour is $-150 \mathrm{~m}$ isobath. Bathymetric map from Michaud et al. (2006) with contours each $500 \mathrm{~m}$. Straight thin lines are the seismic profiles used to contour the maps. Onshore faults from Reyes and Michaud (2012).

A) TWTT isopach map of seismic unit L1 along the three margin segments; contour lines each 200ms. Note the NNW-trending depocenters and faults in the Central-South segment, and the EW-trending faults in the Central-North segment. B) TWTT isopach map of seismic unit L2 along the Central-North and North segments showing thin (100-300 ms) deposits; contour lines each 100 ms. C) TWTT isopach map of seismic unit L3 showing thick $(\sim 1500$ ms) depocenters along the Central-North and North segments; contour lines each $100 \mathrm{~ms}$. Red double arrows are the Manta anticline (trending NS) and the Pedernales structural high (trending EW); black lines show the Bahía-Jama strike slip fault system. D) TWTT isopach map of seismic unit L4 showing localized depocenters, contour lines each $100 \mathrm{~ms}$. E) TWTT isopach map of seismic unit L5 showing the mosaic of small depocenters and uplifted highs along the three margin segments, contour lines each $50 \mathrm{~ms}$.

Figure 11: Seismic profile $900(\mathrm{VE}=4)$. Location on Figure 2. L1 to L5 and Ub to U5 as in Fig 5. This profile images the strike-slip fault system that deforms the Bahía-Jama depocenter. The fault system was active during deposition of subunits L3a and L3b.

Figure 12: Seismic profile 1028 (VE $=4)$ across the North segment. Location on Figure 2. L1 to L5 and Ub to U5 as in Fig 5. Note that the acoustic basement is shallow (1 sTWTT), and that units L1a to L3a outcrop at the seafloor.

Figure 13: Correlation between borehole data and seismic units identified in this work. A) Location of seismic profile 441 and Caráquez-1 and Manta-5 wells. B) Correlation between Manta-5 well (modified from Benítez, 1995), Caráquez-1 well and the seismic units identified in this work. $\mathrm{RHOB}=$ density; $\mathrm{SN}=$ Electrical Survey; $\mathrm{CIDC}=$ Calibrated Induction Deep Conductivity. We propose a new interpretation of the Angostura Fm. initially interpreted in the Caráquez-1 well.

Figure 14: Chronostratigraphic evolution of the offshore forearc basin and its correlation with A) the spatial distribution of seismic units L1 to L5 and unconformities U0 to U5, B) the sea- 
level variations from Hansen et al. (2013), (MCO = Miocene Climatic Optimal), C) the convergence rate between the Nazca and South America plates from Somoza and Ghidella (2012), and D) geodynamic events from Lonsdale (2005). E) TWTT isopach map of the forearc basin sedimentary fill (L1 to L5) in Fig 4. The onshore faults are from Reyes and Michaud (2012). Onshore blocks are from Luzieux et al. (2006). The stars correspond to the location of the Carnegie ridge at $5 \mathrm{Ma}$ boundaries (yellow) and present (black) considering the boundaries census largo i. e. from the Grijalva Fracture zone to the Carnegie ridge northern flank (Collot et al., 2009).

Figure 15: Schematic reconstitutions trough time of the offshore forearc wedge. In blue the Carnegie ridge to the Grijalva Fracture zona (GFZ) (Collot et al., 2009) and the $-2500 \mathrm{~m}$ isobath (Michaud et al., 2006) bounds the Carnegie ridge topography. The black continuous barbed line shows the present-day trench location in D, and its hypothetical location in A, B and $\mathrm{C}$, considering a past, non-quantified subduction erosion suggested by the hatched area. Onshore faults (heavy black dotted lines) and Piñón-Cayo Formations (green areas on D) are from Reyes and Michaud (2012). A) Extensional deformation during the Oligocene- early middle Miocene stage. Plate convergence evolution of the Nazca plate with respect to the South American plate from Somoza and Ghidella (2012). Evolution of Farallon plate from Lonsdale (2005). Light grey areas are the offshore depocenters; dark grey areas are the crustal blocks from Luzieux et al., (2006). B) Individualization of the Central-South and Central-North segments during the early Pliocene possibly coincident with the arrival of the Carnegie ridge in the subduction. Pink areas are the uplifted and/or no deposition zones. Black rounded dotted lines show the crest of the Coastal Cordillera. C) Individualization of the North margin segment at the Plio-Pleistocene boundary across the Pedernales structural high and development of the Jama-Bahía strike slip fault system. Red lines are the neotectonic faults. D) Development of a mosaic of small depocenters (light gray) alternating with uplifted zones (pink) during the middle to late Pleistocene, along the entire margin.

\section{References}

Aizprua, C., Witt, C., Johansen, S. E., Barba, D., 2019. Cenozoic Stages of Forearc Evolution Following the Accretion of a Sliver from the Late Cretaceous- Caribbean Large Igneous Province: SW Ecuador- NW Peru. Tectonics, 38, 4, 1441-1465. 
Alvarado, A., Audin, L., Nocquet, J. M., Jaillard, E., Mothes, P., Jarrín, P., Cisneros, D., 2016. Partitioning of oblique convergence in the Northern Andes subduction zone: Migration history and the present-day boundary of the North Andean Sliver in Ecuador. Tectonics, 35, $5,1048-1065$.

Belco Petroleum Ecuador Inc. ,1988. unpublished report

Benítez, S.B., 1995. Evolution géodynamique de la province côtière sud-équatorienne au Crétacé supérieur-Tertiaire. PhD thesis, Université de Grenoble, France, Géologie Alpine 71, 163p. https://tel.archives-ouvertes.fr/tel-00542421/file/These-Benitez-1995.pdf

Brichau S., Reyes P., Michaud F., Gautheron C., Proust J. N., Hernandez M. J., Saillard M., Vacherat A., 2019. First time constraints on Ecuadorian Coastal Cordillera uplift: Geodynamic implications, ISAG, Quito, 1p.

Bristow, C. R., Hoffstetter, R., 1977. Ecuador. Lexique International de Stratigraphie. Paris, v. Va2.

Byrne, D. E, Wang, W., and Davis, D. M., Mechanical role of backstops in the growthof forearcs: Tectonics, v. 12, p. 123-144, 1993

Cantalamessa, G., Di Celma, C. , Ragaini L., Valleria, , G., Landini, W., 2007. Sedimentology and high-resolution sequence stratigraphy of the late middle to late Miocene Angostura Formation (western Borbon Basin, northwestern Ecuador). J. Geol. Soc., London, 164, 653-665,

Clift, P. D., MacLeod, C. J., 1999. Slow rates of subduction erosion estimated from subsidence and tilting of the Tonga forearc. Geology, 27, 5, 411-414

Clift, P. D., Hartley, A. J., 2007. Slow rates of subduction erosion and coastal underplating along the Andean margin of Chile and Peru. Geology, 35, 6, 503-506.

Collot, J.-Y., Marcaillou, B., Sage F., Michaud, F., Agudelo, W., Charvis, P., Graindorge, D., Gutscher, M. A., Spence, G., 2004. Are rupture zone limits of great subduction earthquakes controlled by upper plate structures?: evidence from multichannel seismic reflection data 
acquired across the northern Ecuador - southwest Colombia margin, J. Geophy. Res.- Solid Earth 109, 1-14,

Collot, J.-Y., Michaud, F., Alvarado, A., Marcaillou, B., Sosson, M., Ratzov, G. , Migeon, S. , Calahorrano, A., Pazmino, A., 2009. Vision general de la morfologia submarina del margen convergente de Ecuador-Sur de Colombia : implicaciones sobre la transferencia de masa y la edad de la subduccion de la Cordillera de Carnegie, in: Geologia y geofisica marina y terrestre del Ecuador : desde la costa continental hasta las Islas GalápagosCollot, , J.-Y., Sallares, V., Pazmino, N., (Eds), , CNDM ; IRD ; INOCAR, Guayaquil (ECU) ; Marseille (FRA) ; Guayaquil, 47-74.

Collot, J. Y., Sanclemente, E., Nocquet, J. M., Leprêtre, A., Ribodetti, A., Jarrin, P., Charvis, P., 2017. Subducted oceanic relief locks the shallow megathrust in central Ecuador. J. Geophy. Research-Solid Earth, 122, 5, 3286-3305.

Collot, J. Y., Ratzov, G., Silva P., Proust, J-N, Migeon, S., Hernandez, M-J. Michaud, F, Pazmino, A, Barba, D., Alvarado, A., Khumara S., 2019. The Esmeraldas Canyon: a helpful marker of the Pliocene-Pleistocene tectonic deformation of the north Ecuador southwest Colombia convergent margin. Tectonics, 38. https://doi.org/10.1029/2019TC005501

Daly M.C., 1989. Correlations Between Nazca/Farallon Plate Kinematics and Forearc Basin Evolution in Ecuador. Tectonics, 8, 4, 769-790.

Deniaud, Y., 2000. Enregistrements sédimentaire et structural de l'évolution géodynamique des Andes Equatoriennes au cours du Néogène : Etude des bassins d'avant-arc et bilans de masse, PhD thesis, 157 pp, Université Joseph Fourier, Grenoble. http://horizon.documentation.ird.fr/exl-doc/pleins_textes/divers14-01/010027994.pdf

Di Celma, C., Cantalamessa, G., Landini, W., Ragaini, L., 2010. Stratigraphic evolution from shoreface to shelf-indenting channel depositional systems during transgression: Insights from the lower Pliocene Súa Member of the basal Upper Onzole Formation, Borbón Basin, northwest Ecuador. Sedimentary Geology 223, 162-179. 
Dickinson, W. R., Seely, D. R., 1979. Structure and stratigraphy of forearc regions. AAPG Bull., 63, 1, 2-31.

Dickinson, W. R., 1995. Forearc basins, in: Busby, C.J., Ingersol R.V., (Eds.), Tectonics of sedimentary basins, 6, Oxford, United Kingdom, Blackwell Science, 221-261.

Draut A.E, Clift P.D., 2013. Differential preservation in the geologic record of intraoceanic arc sedimentary and tectonic processes.bEarth-Science Reviews 116, 57-84, https://doi.org/10.1016/j.earscirev.2012.11.003

Evans, C. D. R., Wittaker, J. E. , 1982. The geology of the western part of the Borbon Basin, northwest Ecuador : trench forearc geology. Geol. Soc. London, 10, 191-200.

Feininger, T., Bristow, C. R., 1980. Cretaceous and Paleogene geologic history of coastal Ecuador. Geologische Rundschau, 69, 3, 849-874.

Feininger, T., 1987. Allochthonous terranes in the Andes of Ecuador and northwestern Peru. Canadian Journal of Earth Sciences 24, 266-278.

Funnell, M. J., Peirce, C., Stratford, W. R., Paulatto, M., Watts, A. B., Grevemeyer I., 2014. Structure and deformation of the Kermadec forearc in response to subduction of the Pacific oceanic plate. Geophysical Journal International, Volume 199, Issue 2, November, 2014, Pages 1286-1302, https://doi.org/10.1093/gji/ggu330

Gailler, A., Charvis, P., Flueh, E. R., 2007. Segmentation of the Nazca and South American plates along the Ecuador subduction zone from wide angle seismic profiles. Earth Planet. Sci. Lett., 260, 3-4, 444-464.

Gutscher M.A, Malavieille, J.S.L., Collot J.-Y. 1999. Tectonic segmentation of the North Andean margin: impact of the Carnegie Ridge collision. Earth Planet. Sci. Lett., 168, 255270. 
Graindorge, D., Calahorrano, A., Charvis, P., Collot, J. Y., Bethoux, N., 2004. Deep structures of the Ecuador convergent margin and the Carnegie Ridge, possible consequence on great earthquakes recurrence interval. Geophysical Research Letters, 3, (4).

Hampel, A. and Kukowski, N., 2004. Ridge subduction at an erosive margin:The collision zone of the Nazca Ridge in southern Peru. Journal of Geophysical Research, Vol. 109, B02101, Doi:10.1029/2003jb002593

Hansen J, Sato M, Russell G, Kharecha P., 2013. Climate sensitivity, sea level and atmospheric carbon dioxide. Philos. Trans. R. Soc. London, A371: 20120294. http://dx.doi.org/10.1098/rsta.2012.0294

Hartley, A. J., May, G., Chong, G., Turner, P., Kape, S. J., Jolley, E. J., 2000. Development of a continental forearc: A Cenozoic example from the Central Andes, northern Chile. Geology, 28, 4, 331-334.

Hughes, R.A., Pilatasig, L.F., 2002. Cretaceous and Tertiary terrane accretion in the Cordillera

Occidental of the Andes of Ecuador. Tectonophysics 345, 29-48.

Jaillard, E., Ordoñez, M., Benitez, S., Berrones, G., Jimenez, N. , Montenegro, G. , Zambrano, I., 1995. Basin Development in an accretionary, oceanic-floored fore-arc setting: Southern coastal Ecuador during late Cretaceous -Late Eocene Time, in: Tankard, A. J., Suarez, S. R., Welsink H. J. (Eds.), Petroleum Basins of South America, AAPG Memoir 62, 20, 615-631.

Jaillard, E., Benitez, S., Mascle, G. H., 1997. Les déformations paléogenes de la zone d'avant-arc sud-équatorienne en relation avec l'évolution géodynamique. Bull. Soc. Géol., France, 168, 4, 403-412.

Jaillard E., Hérail G., Monfret T., Díaz-Martínez E., Baby P., Lavenu A., and Dumont J.F. 2000. Tectonic Evolution of the Andes of Ecuad or, Per u, Bo livia, and North 
Chile, in: Cordani U.G., Milani E.J., Thomaz Filho A., and Campos D.A. (Eds.) "Tectonic evolution of South America", 481-559

Jaillard, E., Lapierre, H., Ordoñez, M., Alava, J. T., Amortegui, A., Vanmelle, J., 2009. Accreted oceanic terranes in Ecuador: southern edge of the Caribbean Plate?. Geol. Soc. Lond., Spec. Publ., 328, 1, 469-485. https://doi.org/10.1144/SP328.19

Kerr, A.C., Aspden, J.A., Tarney, J., Pilatasig, L.F., 2002. The nature and provenance of accreted oceanic terranes in western Ecuador: geochemical and tectonic constraints. Journal of the Geological Society 159, 577-594.

Karig, D. E., Sharman G. F., 1975. Subduction and accretion in trenches. Geol. Soc. Am. Bull., 86, 377-389.

Karig, D. E., Sarewitz, D. R., Haeck, G. D., 1986. Role of strike-slip faulting in the evolution of allochthonous terranes in the Philippines. Geology, 14, 10, 852-855.

Kimbrough, D. L., Smith, D. P., Mahoney, J. B., Moore, T. E., Grove, M., Gastil, R. G., Fanning, C. M., 2001. Forearc-basin sedimentary response to rapid Late Cretaceous batholith emplacement in the Peninsular Ranges of southern and Baja California. Geology, 29, 6, 491494.

Lallemand S, Heuret A, Boutelier D, 2005. On the relationships between slab dip, back-arc stress, upper plate absolute motion and crustal nature in subduction zones. Geochemistry, Geophysics, Geosystems, http://dx.doi.org/10.1029/2005GC000917.

Laursen, J., Scholl, D. W., von Huene, R., 2002. Neotectonic deformation of the central Chile margin: Deepwater forearc basin formation in response to hot spot ridge and seamount subduction. Tectonics, 21 5, 1-27.

Lonsdale, P. ,1978. Ecuadorian subduction system. AAPG Bull., 62, 12, 2454-2477.

Lonsdale, P., Klitgord, K. D., 1978. Structure and tectonic history of the eastern Panama Basin. Geol. Soc. Am. Bull., 89, 7, 981-999. 
Lonsdale, P., 2005. Creation of the Cocos and Nazca plates by fission of the Farallon plate. Tectonophysics, 404, 3-4, 237-264.

Lopez Ramos, E., 2009. Evolution tectono-stratigraphique du double bassin avant - arc de la marge convergente Sud Colombienne - Nord Equatorienne pendant le Cénozoïque., $\mathrm{PhD}$ thesis, 349p, Université de Nice Sophia Antipolis, Nice, France. http://horizon.documentation.ird.fr/exl-doc/pleins_textes/divers11-02/010048522.pdf

Luzieux, L. D. A., Heller, F., Spikings, R., Vallejo, C. F., Winkler, W., 2006. Origin and Cretaceous tectonic history of the coastal Ecuadorian forearc between $1 \mathrm{~N}$ and $3 \mathrm{~S}$ : Paleomagnetic, radiometric and fossil evidence. Earth Planet. Sci. Lett., 249, 3-4, 400-414.

Mamberti, M., Lapierre, H., Bosch, D., Jaillard, E., Ethien, R., Hernandez, J., \& Polve,M. (2003). Accreted fragments of the Late Cretaceous Caribbean- Colombian Plateau in Ecuador. Lithos, 66(3-4), 173-199.

Marcaillou, B., J.-Y. Collot, 2008. Chronostratigraphy and tectonic deformation of the North Ecuador - South Colombian Fore-arc Basin. Mar. Geol., 255, 1-2, 30-44,

Marcaillou, B., Collot, J.-Y., Ribodetti, A., d'Acremont, E., Mahamat, A.-A., Alvarado A., 2016. Seamount subduction at the North-Ecuadorian convergent margin: Effects on structures, inter-seismic coupling and seismogenesis. Earth Planet. Sci. Lett., 433, 146-158.

Martillo C., 2016. Enregistrements stratigraphiques des cycles glacio-eustatiques et de la deformation durant le Pleistocene le long de la marge centrale d'Equateur, $\mathrm{PhD}$, Université de Nice, Sophia Antipolis, Nice, France, 239p. http://www.theses.fr/2016NICE4020

McCaffrey, R., Zwick, P. C., Bock, Y., Prawirodirdjo, L., Genrich, J. F., Stevens, C. W., Puntodewo, S.S.O., Subarya, C., 2000. Strain partitioning during oblique plate convergence in northern Sumatra: Geodetic and seismologic constraints and numerical modeling. J. Geophys. Research-Solid Earth, 105, B12, 28363-28376. 
McNeill, L. C., Goldfinger, C., Kulm, L. D., Yeats, R. S., 2000. Tectonics of the Neogene Cascadia forearc basin: Investigations of a deformed late Miocene unconformity. Geol. Soc. Am. Bull., 112, 8, 1209-1224.

Meschede, M., Barckhausen, U., 2001. The relationship of the Cocos and Carnegie Ridges: age constraints from paleogeographic reconstructions. Int. J. Earth Sci. 90, 386- 392.

Michaud F, Collot J-Y, Alvarado A, Lopez-Ramos, E. y el personal científico y técnico del INOCAR, 2006. República del Ecuador, Batimetría y Relieve Continental, publicación IOACVM-02- Post. INOCAR, Guayaquil

Michaud F, Witt C, Royer J-Y., 2009. Influence of the Carnegie ridge subduction on Ecuadorian geology: reality and fiction: in Kay, S.M., Ramos, V.A., and Dickinson, W.R., eds., Backbone of the Americas: Shallow Subduction, Plateau Uplift, and Ridge and Terrane Collision: Geol. Soc. Am. Memoir 204, 217-228.

Michaud, F., Proust, J. N., Collot, J. Y., J. F. Lebrun, C. Witt, G. Ratzov, H. Pouderoux, C. Martillo, M. J. Hernandez, G. Loayza, L. Penafiel, L. Schenini, A. Dano, M. Gonzalez, D. Barba, L. De Min, G. Ponce, A. Urresta, M. Calderon, 2015. Quaternary sedimentation and active faulting along the Ecuadorian shelf: preliminary results of the ATACAMES Cruise (2012), Mar. Geophys. Res., 36, 91-98, 10.1007/s11001-014-9231-y.

Miller, K., G., Kominz, M. A., Browning, J. V., Wright, J. D., Mountain, G. S., Katz, G. S., Sugarman, P. J., Cramer, B. S., Christie-Blick, N., Pekar, S. F., 2005. The Phanerozoic Record of Global Sea-Level Change. Science, 310, 1293, DOI: 10.1126/science.1116412.

Mora, J. A., Oncken, O., Le Breton, E., Mora, A., Veloza, G., Vélez, V., and de Freitas, M., 2018. Controls on forearc basin formation and evolution: Insights from Oligocene to Recent tectono-stratigraphy of the Lower Magdalena Valley basin of northwest Colombia. Marine and Petroleum Geology, 97, 288-310.

Nocquet, J.-M., Villegas-Lanza, J. C., Chlieh, M. Mothes,, P. A., Rolandone, F., Jarrin, P., Cisneros, D., Alvarado, A. , Audin, L., Bondoux, F. , Martin, X. , Font, Y. , Régnier, M., Vallée, M., Tran, T. , Beauval, C., Maguiña Mendoza, J. M., Martinez, W., Tavera, H., 
Yepes, H., 2014. Motion of continental slivers and creeping subduction in the northern Andes, Nature Geoscience, 1-5, doi: 10.1038/NGEO2099.

Noda, A., 2016, Forearc basins: Types, geometries, and relationships to subduction zone dynamics. Geol. Soc. Amer. Bull., 128, 5-6, 879-895, doi: 10.1130/B31345.1

Noda, A. (2018). Forearc basin stratigraphy and interactions with accretionary wedge growth according to the critical taper concept. Tectonics, 37(3), 965-988.

Ordonez, M., Jimenez N., Suarez J., 2006. Micropaleontologia Ecuatoriana; Datos bioestratigràficos y paleoecologicos de las cuencas: graben de Jambelì, Progresso, Manabì, Esmerladas y Oriente; del leventamiento de la Penìnsula de Santa Elena, y de las cordilleras Chongon Colonche, Costero y Occidental, edited by Centro de Investigaciones Geologicas Guayaquil, p. 634, Petroproduccion, Guayaquil, Ecuador.

Pedoja, K., Dumont, J. F., Lamothe, M., Ortlieb, L., Collot, J. Y., Ghaleb, B., Labrousse, B., 2006, Plio-Quaternary uplift of the Manta Peninsula and La Plata Island and the subduction of the Carnegie Ridge, central coast of Ecuador. J. S. Am. Earth Sc., 22, 1-2, 1-21.

Pennington, W. D., 1981. Subduction of the eastern Panama Basin and seismotectonics of northwestern South America. J. Geophys. Research-Solid Earth, 86, B11, 10753-10770.

Proust, J. N., Martillo, C., Michaud, F., Collot, J. Y., Dauteuil, O., 2016. Subduction of seafloor asperities revealed by a detailed stratigraphic analysis of the active margin shelf sediments of Central Ecuador. Mar. Geol., 380, 345-362.

Quintana Petroleum Corp., 1971. unpublished report, in Hernández M. J., 2012. El sistema de fallas de Jama en la plataforma continental (off-shore) del margen ecuatoriano, Tesis Ingenieria Geologica, 143p. http://bibdigital.epn.edu.ec/handle/15000/4571

Reyes, P., Michaud, F., 2012. Mapa Geologico de la Margen Costera Ecuatoriana 849 (1/1500000), EP PetroEcuador-IRD Quito, Ecuador. 
Reyes, P., 2013. Évolution du relief le long des marges actives : Etude de la déformation Plio- Quaternaire de la cordillère côtière d'Equateur, $\mathrm{PhD}$ tesis, Université de Nice- Sophia Antipolis, Nice, France. 279p. https://tel.archives-ouvertes.fr/tel00835324/file/2013NICE4006.pdf

Reyes P., Valarezo M, Córdova J, Michaud F., 2018. Quantitative morphometric analysis of the Jama River profile in a tectonically active margin (Northwestern Ecuador). Journal of Mountain Science 15, 5, https://doi.org/10.1007/s11629-017-4751-y

Ryan, H. F., Scholl, D. W., 1989. The evolution of forearc structures along an oblique convergent margin, central Aleutian arc. Tectonics, 8, 3, 497-516.

Sage, F., Collot, J. Y., Ranero, C. R., 2006. Interplate patchiness and subduction-erosion mechanisms: Evidence from depth-migrated seismic images at the central Ecuador convergent margin. Geology, 34, 12, 997-1000.

Sander Geophysics Limited, 2011. Levantamiento Aerogravimétrico y Aeromagnetométrico - Area Litoral, Sander Geophysics Limited (SGL), Informe Técnico, Unpublished., 116p.

Sandwell, D. T., Müller, R. D., Smith, W. H., Garcia, E., Francis, R., 2014. New global marine gravity model from CryoSat-2 and Jason-1 reveals buried tectonic structure. Science, 346 6205, 65-67.

Somoza, R., Ghidella, M. E., 2012. Late Cretaceous to recent plate motions in western South America revisited. Earth Planet. Sci. Lett., 331, 152-163.

Spikings, R. A., Crowhurst, P. V., Winkler, W., Villagomez, D., 2010. Syn- and postaccretionary cooling history of the Ecuadorian Andes constrained by their in-situ and detrital thermochronometric record. J. South Am. Earth Sci., 30, 121-133, 10.1016/j.jsames.2010.04.002.

Stern, R. J. ,2002. Subduction zones. Reviews of geophysics, 40 (4), 3-1. 
Trenkamp, R., J. N. Kellogg, J. T. Freymueller, and P. Mora, H., 2002. Wide plate margin deformation, southern Central America and northwestern South America, CASA GPS observations. J. South Am. Earth Sci., 15, 157-171.

Vallejo, C., Winkler, W., Spikings, R.A., Luzieux, L., Heller, F., Bussy, F., 2009. Mode and timing of terrane accretion in the forearc of the Andes in Ecuador, in Kay, S.M., Ramos, V.A., and Dickinson, W.R., eds., Backbone of the Americas: Shallow Subduction, Plateau Uplift, and Ridge and Terrane Collision. Geol. Soc. Am. Memoir 204, doi: $10.1130 / 2009.1204(09)$

Von Huene, R., and Scholl, D. W. 1991. Observations at convergent margins concerning sediment subduction, subduction erosion, and the growth of continental crust. Reviews of Geophysics, 29(3), 279-316.

Witt, C., Bourgois, J., Michaud, F., Ordoñez, M., Jiménez, N., Sosson, M., 2006. Development of the Gulf of Guayaquil (Ecuador) during the Quaternary as an effect of the North Andean block tectonic escape. Tectonics, 25, TC3017. https://doi.org/10.1029/2004TC001723

Witt C., Reynaud J.Y., Barba D., Poujol M., Aizprua C., Rivadeneira M., Amberg C., 2019. From accretion to forearc basin initiation: The case of SW Ecuador, Northern Andes. Sedimentary Geology, 379, 138-157.

Xie, X., Heller, P. L., 2009. Plate tectonics and basin subsidence history. Geol. Soc. Amer. Bull, 121, 1-2, 55-64. 


\section{Declaration of interests}

$\bigotimes$ The authors declare that they have no known competing financial interests or personal relationships that could have appeared to influence the work reported in this paper.

$\square$ The authors declare the following financial interests/personal relationships which may be considered as potential competing interests:

Sincerely,

María José Hernández

Elia d'Acremont

François Michaud

Jean-Yves Collot

Jean-Noël Proust 


\section{Authors contributions}

María José Hernández: Conceptualization, Methodology, Software, Investigation, Data Curation, Writing - Original Draft and Writing - Review \& Editing

François Michaud: Conceptualization, Methodology, Validation, Formal analysis, Investigation, Resources, Writing - Original Draft, Writing - Review \& Editing, Visualization Jean-Yves Collot: Conceptualization, Methodology, Validation, Formal analysis, Investigation, Resources, Writing - Original Draft, Writing - Review \& Editing, Visualization

Jean-Noël Proust: Conceptualization, Methodology, Resources, Writing - Review \& Editing

Elia d'Acremont: Conceptualization, Methodology, Resources, Writing - Original Draft 


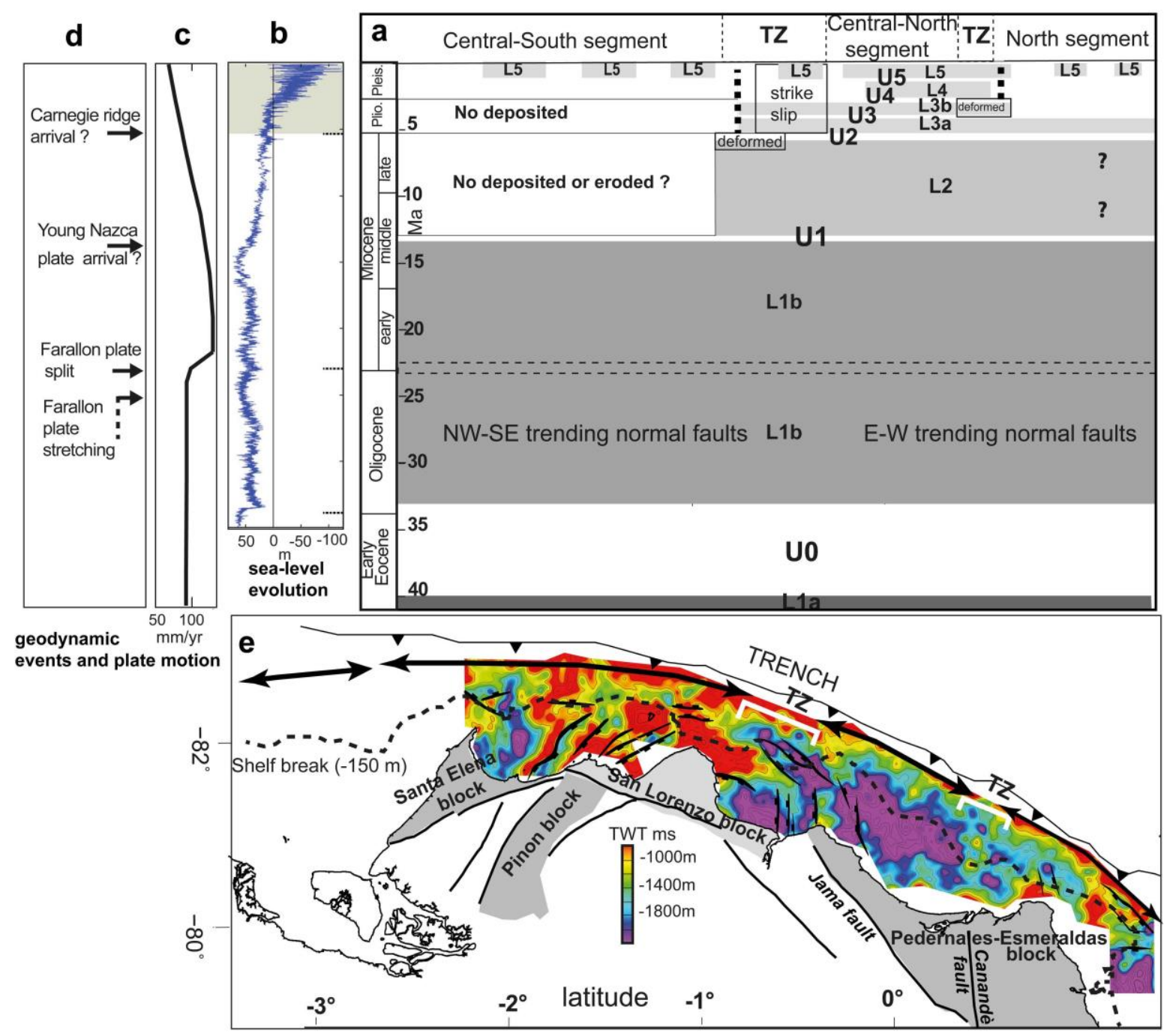

Graphical abstract 


\section{Highlights}

- The Ecuadorian margin is a remarkable example of the evolution of a non-accretionary type of forearc basin

- Trench-parallel extension deformed the margin during the Oligocene to early-middle Miocene

- Three margin segments are identified: the Central-South and Central-North segments were individualized during the early Pliocene, and the North Segment during the Pliocene early-Pleistocene

- Intersegment transition zones are correlated with onshore inherited fault zones, and were reactivated during major geodynamic events, in particular the Carnegie ridge subduction

- The middle to late Pleistocene depocenters developed along the continental shelf reflects the subduction of the topographically irregular Carnegie ridge 